
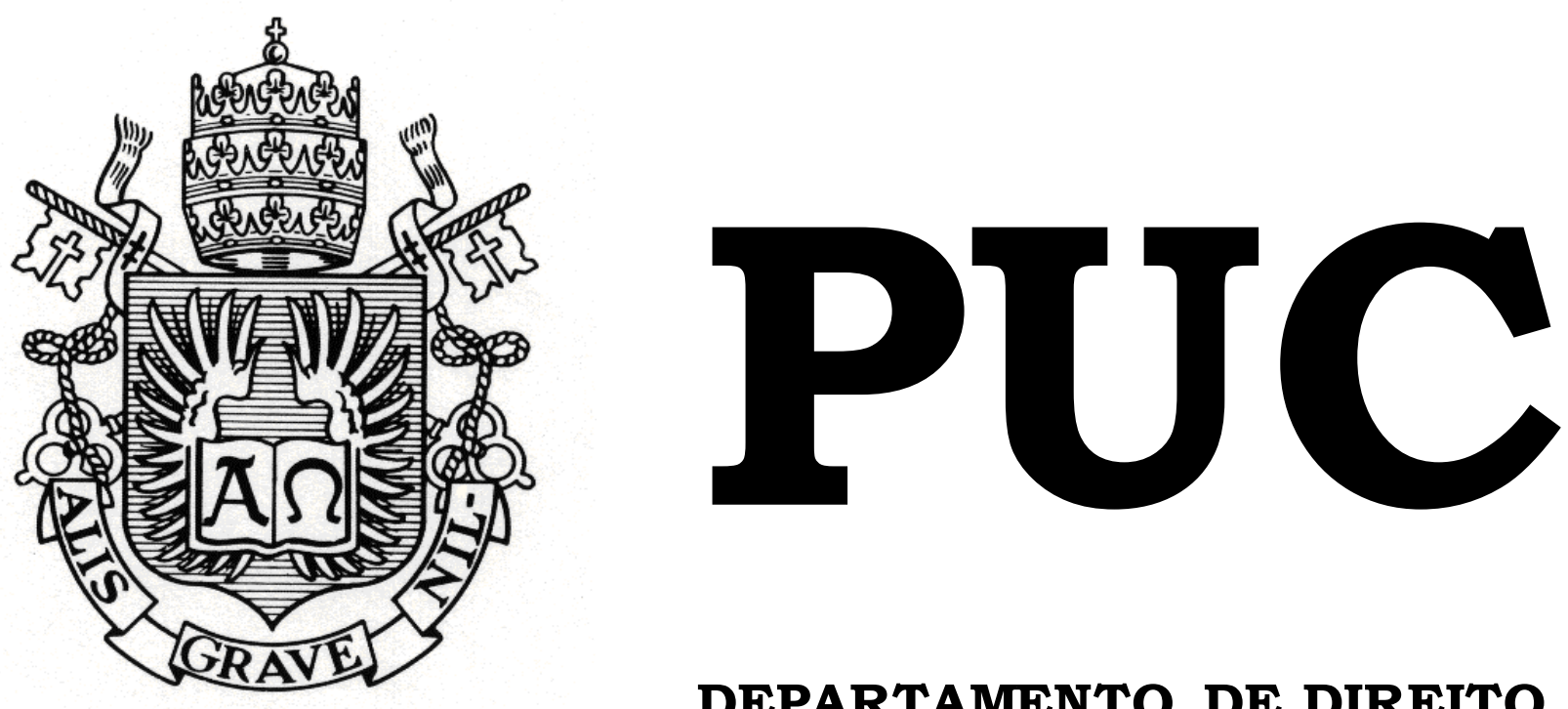

DEPARTAMENTO DE DIREITO

O Sistema de Valorização de Precedentes: considerações sobre a ratio decidendi

por

JÉSSICA HALLANA ALVES SOBRAL

ORIENTADOR: Bruno Garcia Redondo COORIENTADOR: Fábio Carvalho Leite

2016.2

PONTIFÍCIA UNIVERSIDADE CATÓLICA DO RIO DE JANEIRO

RUA MARQUÊS DE SÃO VICENTE, 225 - CEP 22453-900

RIO DE JANEIRO - BRASIL 


\title{
O Sistema de Valorização de Precedentes: considerações sobre a ratio decidendi
}

\author{
por
}

\section{JÉSSICA HALLANA ALVES SOBRAL}

\begin{abstract}
Monografia apresentada ao Departamento de Direito da Pontificia Universidade Católica do Rio de Janeiro (PUC-Rio) para a obtenção do Título de Bacharel em Direito.
\end{abstract}

Orientador: Bruno Garcia Redondo Coorientador: Fábio Carvalho Leite 


\section{AGRADECIMENTOS}

À minha mãe, Jenny, por tudo o que tenho e pelo que sou. Obrigada por ter sido a melhor mãe e pai que pôde e por estar sempre ao meu lado.

À minha irmã, Joyce, pelo amor e companheirismo desde a infância.

Ao Igor, meu maior companheiro, por representar vários papéis na minha vida. Obrigada por todo o amor, carinho, apoio, leveza, bom humor e paciência.

À Naila Horesh, por todo o apoio na estrada do autoconhecimento. Sinto saudades. Gostaria de ter podido te dar um último abraço e te agradecer por tudo.

Aos meus amigos, que são a família que escolhi, por entenderem a minha ausência durante o tempo de estudo para a elaboração deste trabalho.

À PUC-Rio, por tornar possível a melhor etapa da minha vida. Me sinto privilegiada por ter tido a oportunidade de estudar em uma das melhores universidades do Brasil.

Ao professor Bruno Redondo, meu orientador, pela confiança, pelo direcionamento e conteúdo passados. Meus sinceros agradecimentos.

Ao professor Fábio Leite, meu coorientador, pelas ideias trocadas e opiniões sinceras sobre este trabalho. Sua participação foi essencial. Muito obrigada.

À Maria Isabel Tolipan, minha primeira amiga da PUC, por estar comigo do início ao fim e por ter dividido comigo momentos tão especiais. Sei que estaremos juntas sempre nessa nova etapa que começará a partir de agora.

Por fim, agradeço aos meus queridos colegas de turma, em especial à Deborah Torres, Felipe Altberg, Henry Azulai, Juliana Tonini, Maria Eduarda Gamborgi, Paula Lemos e Renato Gomide. Vocês foram os melhores presentes que ganhei na minha trajetória universitária. Sem vocês essa experiência não teria sido tão especial. 


\section{RESUMO}

O Novo Código de Processo Civil (Lei 13.105/2015) possui o objetivo de implementar um sistema de valorização de precedentes, inovando no ordenamento jurídico brasileiro ao prever um dever de uniformização da jurisprudência. Entretanto, para que seu objetivos seja alcançado, é fundamental que se possa extrair do precedente a norma geral e abstrata que poderá ser aplicada a casos semelhantes futuros, o que nem sempre é tarefa fácil na atual prática decisória dos tribunais brasileiros.

O objetivo inicial do presente estudo é compreender as razões para se adotar um sistema de valorização de precedentes e em seguida analisar o tema tal como disposto pelo Novo Código. Dito isso, passaremos a analisar o conceito de ratio decidendi, como identificá-la e alguns dos problemas do atual sistema brasileiro que podem dificultar, ou mesmo impossibilitar, sua identificação.

Palavras-chave: Precedentes. Ratio decidendi. Novo Código de Processo Civil. Fundamentação. Jurisprudência. Súmula. Ementismo. Dispersão de Fundamentos. Regra da Maioria Decisória Simples. Supremo Tribunal Federal. Deliberação interna. Decisão Colegiada. 


\section{SUMÁRIO}

INTRODUÇÃO ......................................................................................

1. Por que adotar um sistema de respeito aos precedentes? ..............8

1.1. Treat like cases alike ……………………………….........................

1.2. Razões deontológicas para a adoção de um sistema de valorização de

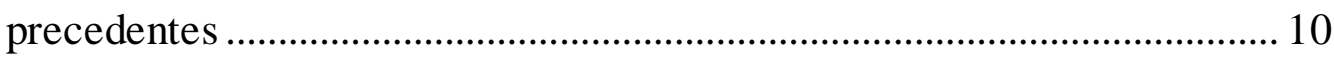

1.3. Efeitos pragmáticos da adoção de um sistema de valorização de

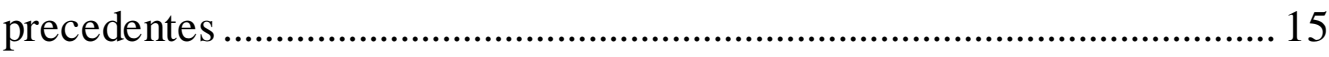

1.4. Argumentos contrários à adoção de um sistema de valorização de

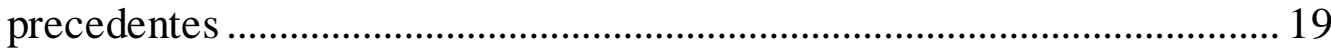

1.5. Insuficiência do texto legal e a necessidade de respeito aos precedentes como forma de controle das decisões judiciais ..................... 22

2. Os precedentes no Novo código de Processo Ci vil ..................................... 26

2.1. O art. 927 e suas possíveis interpretações ............................................ 28

2.2. O dever de moti vação das decisões judiciais ....................................... 30

2.3. Deveres gerais dos tribunais relacionados ao sistema de

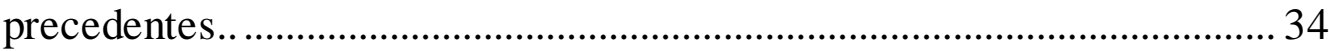

3. Determinação da norma emergente do precedente …………………...... 39

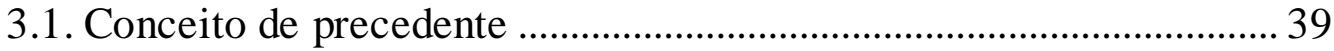

3.2. Precedente, jurisprudência e súmula ……………………………….... 40

3.3. Requisitos para a formação de um precedente no Direito

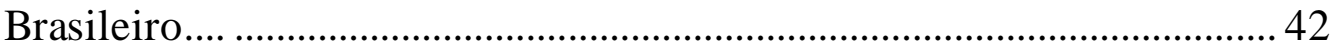

3.4. Elementos do precedente: ratio decidendi e obiter dictum ............... 44

3.5. Como identificar a ratio decidendi? ...................................................... 46

3.6. Grau de generalidade da Ratio ............................................................ 52

4. Obstácul os para a identificação da ratio decidendi..................................56

4.1. A cultura do "ementismo" ......................................................................56

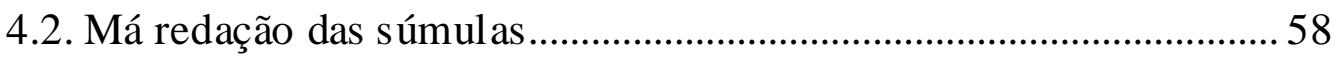

4.3. Falhas na deliberação interna dos tribunais ........................................... 60 
4.3.1. Divergência quanto aos pontos relevantes para a resolução das controvérsias 62

4.3.2. A regra da maioria decisória simples ......................................... 64

4.3.3. O excesso de personalismo argumentativo .................................. 66

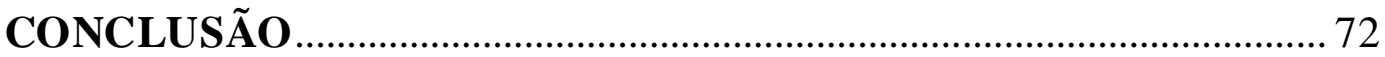

REFERÊNCIAS BIBLIOGRÁFICAS ….............................................. 74 


\section{INTRODUÇÃO}

O Novo Código de Processo Civil, em vigor desde março de 2016, possui a difícil tarefa de modificar a cultura até então dominante no sistema brasileiro, em que precedentes sequer são tratados como persuasivos, e concretizar um sistema de respeito a precedentes.

O judiciário vive momentos de crise ocasionados, principalmente, pela multiplicação exacerbada do estoque de processos, formado, em sua maioria, por demandas repetitivas. Esse cenário impacta negativamente no funcionamento do aparelho estatal, tornando-o extremamente moroso, pouco eficiente e reduzindo a qualidade dos provimentos judiciais.

Diante disso, os defensores de um sistema de precedentes entendem que não seria eficiente que o Judiciário decidisse cada uma dessas demandas repetitivas isoladamente quando já houvesse pronunciamento judicial sobre o assunto. Além disso, sustentam que não seria justo dar tratamento diferenciado para questões essencialmente iguais.

Inicialmente, buscamos agrupar algumas das razões deontológicas e pragmáticas para a adoção de um sistema de precedentes, bem como alguns dos possíveis argumentos contrários à adoção do sistema.

Dito isso, analisaremos os precedentes tal como dispostos nos enunciados normativos da nova lei, em especial nos arts. 489, §1 $1^{\circ}, 926$ e 927. Traçaremos, ainda, considerações a respeito das interpretações que vêm sendo conferidas a esses dispositivos nos primeiros meses de vigência do Novo Código.

Entretanto, apesar de inovar no ordenamento e prever um dever de uniformização, integridade e coerência da jurisprudência, a nova lei não define conceitos relevantes para uma compreensão mais clara a respeito do tema. Dessa forma, buscamos o auxílio da doutrina para definir o que seriam precedentes, e como podemos identificar a ratio decidendi, a norma 
geral e abstrata será aplicada em casos futuros que versem sobre a mesma tese jurídica.

Ocorre que, não podemos interpretar um sistema de precedente tendo por base a atual prática judiciária brasileira, que não delimita bem os conceitos de ementa dos julgados, ratio decidendi e obiter dictum. Além disso, sabemos que comumente as decisões judiciais não anunciam claramente as razões de decidir aplicadas ao caso sob julgamento, tornando difícil - quando não impossível - a identificação da ratio.

Por isso, buscamos demonstrar, ao final, alguns desses possíveis problemas que dificultam a identificação da ratio decidendi e em que medida alguns deles estariam relacionados à falha no processo deliberativo dos tribunais. 


\section{Por que adotar um sistema de respeito aos precedentes?}

\subsection{Treat like cases alike}

Imagine que um pai tenha permitido que o filho mais velho ficasse acordado até mais tarde para assistir a um programa de TV. O irmão mais novo, naturalmente, teria a mesma expectativa ${ }^{1}$.

Entretanto, suponhamos que o pai apenas tenha atendido ao pedido do mais velho para que o mesmo pudesse assistir a uma reportagem que o ajudaria na tarefa escolar e que o mais novo apenas queria assistir desenho.

Dito isso, é de se esperar que o pai recusasse o pleito do caçula, pois, no seu caso, ver TV não era medida excepcional e necessária para fazer seu dever de casa, como ocorreu com o mais velho. Seria preciso compreender os fundamentos da decisão do pai para extrair deles uma regra.

Anos depois, o avô das crianças veio a falecer e o velório começaria bem tarde. Recorrendo aos fundamentos das decisões anteriores, os irmãos concluiriam que poderiam alterar seu horário de sono, uma vez que: i) a despedida de um ente querido é uma situação excepcional; ii) era uma situação muito mais importante que uma tarefa escolar. Ou seja, os filhos previram adequadamente a conduta do pai com base em suas decisões anteriores.

A partir de então, criou-se uma regra: "será autorizado que um filho durma mais tarde, desde que para atender a fim importante e excepcional”. Além disso, pode-se extrair os standards: o cumprimento de um trabalho escolar e a despedida de um ente querido são considerados fins importantes e excepcionais.

\footnotetext{
1 Esse exemplo é de Patrícia Perrone Campos Mello inspirado em Frederick Schauer. MELLO, Patrícia Perrone Campos. Precedentes. Rio de Janeiro: Renovar. 2008. p. 114-116.
} 
Continuando o exemplo, suponhamos que, objetivando compreender os processos decisórios do pai, o caçula tenha pleiteado postergar o horário de sono para se despedir de seu jogador de futebol favorito, que embarcaria para o Japão naquele dia para cumprir contrato de 10 anos. O pai negou-lhe a solicitação, esclarecendo que tal evento não equivalia ao evento "morte" e que o jogador de futebol favorito não estaria equiparado a um "ente querido", por estar essa classificação reservada a amigos e parentes muito próximos.

O exemplo acima serve para demonstrar que, partir das decisões preferidas pelo pai, os filhos foram capazes de extrair regras que serão aplicadas a situações futuras. Ou seja, foram capazes de extrair enunciados mais genéricos que seriam aplicados futuramente. Esse é justamente o modo de operar do stare decisis no Common Law, e exige que tribunais sigam seus próprios precedentes e aqueles estabelecidos pelas cortes superiores.

A máxima do "treat like cases alike" (casos similares devem ser decididos da mesma forma) constitui um princípio universal da administração da justiça e já era conhecido e respeitado na Babilônia antes mesmo do reino de Hamurabi ${ }^{2}$.

Por isso, pensar na ideia de precedentes significa ir além do âmbito jurídico. A expectativa de receber tratamento idêntico em situações que guardam profunda semelhança é bastante razoável.

Em inúmeros casos, dentro ou fora da lei, o fato de que algo foi feito anteriormente fornece, por si só, uma razão para se fazer daquela forma novamente ${ }^{3}$. Nessa linha, antinatural seria não respeitar precedentes ${ }^{4}$.

\footnotetext{
2 CRISCUOLI, Giovanni. Introduzione allo studio del diritto inglese - Le fonti. Milano: Giuffrè, 1994. Apud MARINONI, Luiz Guilherme. Precedentes Obrigatórios. 4a ed. rev. atual. e amp. São Paulo: Editora Revista dos Tribunais, 2016. p. 93.

${ }^{3}$ Appeals to precedent do not reside exclusively in courts of law. Forms of argument that may be concentrated in the legal system are rarely isolated there, and the argument from precedent is a prime example of nonexclusivity of what used to be called "legal reasoning". Think of the child who insis tis that he should not to have to wear short pants to school because his older brother was
} 
Qualquer demandante que busque a prestação jurisdicional possui uma legítima expectativa baseada em decisões de casos anteriores. Se dissermos a um leigo que o Judiciário pode dar soluções distintas a casos idênticos, sem que haja uma forte razão para tal e sem observar o que já foi decidido anteriormente, certamente ele não entenderia.

Manter uniformidade e coerência nas decisões judiciais é de extrema importância para que os cidadãos possam extrair certo grau de previsibilidade, a fim de minimamente direcionar seu comportamento ${ }^{5}$, e para promover confiança no sistema judiciário.

Nos sistemas baseados em precedentes, o juiz, no momento de decidir tem a responsabilidade de dialogar com decisões anteriores, bem como de analisar as possíveis consequências daquela decisão para casos futuros. Trata-se, na verdade, de uma responsabilidade do juiz para com suas próprias decisões anteriores (autorrespeito) e para com o poder judiciário como um todo, na medida em que é parte integrante de um sistema e deve colaborar com a sua coesão e integridade.

O respeito aos precedentes representa, ainda, uma forma de controle objetivo das decisões, reduzindo as possibilidades de decisões arbitrárias.

\subsection{Razões deontológicas para a adoção de um sistema de valorização de precedentes}

A previsibilidade é condição sem a qual não poderia haver segurança jurídica, e esta, consequentemente, é elemento indispensável para a

allowed to wear long pants when he was seven. Or think of the bureaucrat who responds to the supplicant for special consideration by saying that "we've never done it that way before". In countless instances, out of law as well as in, the fact that something was done before provides, by itself, a reason for doing that way again. SCHAUER, Frederick. Precedent. Stanford Law Review, Palo Alto, v. 39, Feb. 1987, p. 572.

4 CRAMER, Ronaldo. Precedentes Judiciais: teoria e dinâmica. Rio de Janeiro: Forense, 2016. p. 52.

${ }^{5}$ As decisões não podem ser incompreensíveis ou destituídas de significado claro, pela mera razão de que o jurisdicionado precisa de parâmetros para definir seu comportamento. Pelo mesmo motivo, o Judiciário deve se preocupar com a uniformidade das suas decisões, haja vista que o cidadão dela depende para pautar suas condutas no desenvolvimento de suas atividades. MARINONI, Luiz Guilherme. Op. cit., p. 87. 
existência de um Estado de Direito ${ }^{6}$. Todo Estado de Direito deve zelar pela estabilidade de suas decisões, percebendo, o quanto antes, que há um grave problema num direito variável de acordo com o caso ${ }^{7}$.

\section{O constitucionalismo moderno ${ }^{8}$ propiciou o aumento do papel} criativo do juiz, concedeu força normativa a princípios e multiplicou a utilização de conceitos vagos. Por isso, conhecer o texto das leis não é suficiente para conferir previsibilidade e segurança, sendo necessário saber que interpretação o judiciário vem conferindo ao texto normativo ${ }^{9} 10$.

\footnotetext{
6 "A segurança jurídica, vista como estabilidade e continuidade da ordem jurídica e previsibilidade das consequências jurídicas de determinada conduta, é indispensável para a conformação de um Estado que pretenda ser 'Estado de Direito'. Embora as Constituições, em geral, e as Cartas de direitos humanos fundamentais - como, por exemplo, a Declaração dos Direitos Humanos da ONU e a Convenção Americana de São José da Costa Rica - não aludam a um direito à segurança jurídica, o constitucionalismo dos nossos dias é consciente de que um Estado de Direito é dela indissociável. A doutrina considera a segurança jurídica como expressão do Estado de Direito, conferindo àquela a condição de subprincípio concretizador do princípio fundamental e estruturante do Estado de Direito". MARINONI, Luiz Guilherme. Op. cit., p. 95.

${ }^{7}$ Ibid. p. 97.

8 "Hoje, o panorama mudou completamente: há profusão de leis; textos legais com vários conceitos vagos, indispensáveis para acompanhar as mudanças sociais; princípios cuja força normativa é relevante, principalmente para hard cases; finalmente, uma sociedade que demanda muitas causas repetitivas no Judiciário. Todas essas circunstâncias reclamam do Poder Judiciário uma atuação uniforme no julgamento dos processos, sobretudo em causas com a mesma tese jurídica". CRAMER, Ronado. Op. cit., p. 55.

9 "A verdade é que o pleno conhecimento do direito legislado não apenas é impossível, mas igualmente dispensável para a previsibilidade e para a tutela de segurança jurídica. Sublinhe-se que o common law, que certamente confere maior segurança jurídica do que o civil law, não relaciona a previsibilidade com o conhecimento das leis, mas sim com a previsibilidade das decisões do Poder Judiciário. O advogado de common law tem possibilidade de aconselhar o jurisdicionado porque pode se valer dos precedentes, ao contrário daquele que atua no civil law, que é obrigado a advertir o seu cliente que determinada lei pode - conforme o juiz sorteado para analisar o caso - ser interpretada em seu favor ou não. A lógica dessa tradição não apenas é inversa, e assim faz surgir a nítida impressão de que o direito do civil law não é tão certo quanto o direito do common law, como milita e se volta contra o próprio sistema, na medida em que estimula a propositura de ações, o aumento da litigiosidade, o acumula de trabalho e o aprofundamento da lentidão do Poder Judiciário". Ibid. p. 98.

${ }^{10}$ Sobre a necessidade de estudo da produção dos tribunais para conhecer a Constituição: "Uma forma de conhecer a jurisdição constitucional é investigar, com métodos e rigor, o produto do trabalho dos tribunais na interpretação da Constituição. Apesar de pouco praticada no Brasil, essa forma de pesquisa é fundamental para compreender a prática constitucional brasileira. Assim como a leitura seca do texto normativo constitucional pode ser enganosa ou insuficiente para descobrir a prática social e institucional, ela também pode conduzir a equívocos quando não se olha para como o dispositivo vem sendo interpretado pelos órgãos estatais incumbidos de sua guarda. SUNDFELD, Carlos Ari; PINTO, Henrique Motta. Três Desafios para Melhorar a Jurisdição Constitucional Brasileira. In. VOJVODIC, Adriana et al (eds.) Jurisdição Constitucional no Brasil. São Paulo: Malheiros, 2012, p. 19-20.
} 
A previsibilidade, portanto, não está atrelada apenas à lei, mas à norma fruto da interpretação judicial do texto legal aplicado ao caso concreto $^{11} 12$.

Através do respeito aos precedentes seria possível uma ordem jurídica minimamente estável para saber o que é ou não direito. Não existe estabilidade do texto legal se sua interpretação é alterada constantemente, muitas vezes dentro de um mesmo órgão decisório ${ }^{13}$.

No Common Law, a segurança jurídica e previsibilidade são tão importantes que, em diversas situações, tribunais optam por ainda aplicar um precedente, mesmo sabendo que este foi ou está em vias de ser superado em virtude da confiança que os jurisdicionados depositam nas decisões judiciais para basear seu comportamento ${ }^{14}$. Não seguir precedentes

\footnotetext{
11 Para uma melhor análise da distinção entre texto e norma ver ÁVILA, Humberto. Teoria dos princípios: da definição à aplicação dos princípios jurídicos. $4^{\mathrm{a}}$ ed., $3^{\mathrm{a}}$ tir. São Paulo: Malheiros, 2005.

12 Ronaldo Cramer destaca a discordância de Humberto Ávila quanto ao termo previsibilidade. O referido autor entende esta não é possível de se atingir e defende que a ordem jurídica pode gerar, no máximo, calculabilidade. Concordamos com Ronaldo Cramer quando este assevera que: "Ao que parece, o desacordo de Humberto Ávila é semântico, isto é, refere-se ao significado de previsibilidade. Entretanto, não se quer afirmar neste trabalho que previsibilidade é previsão absoluta ou exata, mas uma noção razoável dos posicionamentos judiciais e, por conseguinte, da ordem jurídica, para que o cidadão possa saber o que pode fazer ou não.

Assim sendo, o fortalecimento dos precedentes favorece a segurança jurídica, na medida em que cria um estado de previsibilidade, gerando mais segurança para os indivíduos agirem. Logo, evita que o Judiciário seja visto como uma casa de apostas, em que cada órgão julgador pode ter um posicionamento distinto sobre o mesmo caso concreto, independentemente das decisões já proferidas em casos idênticos”. CRAMER, Ronaldo. Op. cit., p. 57.

13 MARINONI, Luiz Guilherme. Op. cit., p. 101.

14 "Entretanto, a constatação de que uma doutrina é socialmente incongruente ou sistemicamente inconsistente não basta para ensejar seu abandono no common law. Isso porque, para tal providência, as razões de justiça (substantive reasons) que fundamentam o referido entendimento deverão ser ponderadas com as razões de segurança jurídica (authority reasons) que justificam a adoção de precedentes com efeitos normativos. Ao considerar a revogação de um precedente, a corte deverá cotejar os fundamentos para promovê-la com os custos relativos: a) à segurança dos cidadãos que confiaram no julgador anterior, b) à quebra da isonomia entre os jurisdicionados, c) às consequências que a medida gerará para a administração da justiça e sua eficiência, d) ao seu impacto (positivo ou negativo) sobre a credibilidade do tribunal. Se, em tal confronto se verificar que os benefícios superam os prejuízos, concluir-se-á em favor da mudança. Caso contrário, é possível que se opte por manter o entendimento equivocado, ante a percepção de que providência diversa seria ainda mais onerosa”. MELLO, Patrícia Perrone Campos, Op. cit., p. 238.
} 
transmite uma ideia de caos e loteria jurisprudencial ${ }^{15}$, gerando descrédito no Poder Judiciário como um todo ${ }^{16}$.

$\mathrm{O}$ art. $6^{\circ}$ do $\mathrm{CPC} / 2015$ prevê o princípio da cooperação e estabelece que todos os sujeitos da relação jurídica processual devem cooperar entre si para que se obtenha, em tempo razoável, decisão de mérito justa e efetiva. Mas, para proferir uma decisão justa e efetiva, o magistrado deve considerar suas próprias decisões anteriores, bem como as das cortes superiores, transmitindo a ideia de um verdadeiro sistema, que age em conjunto. Dessa forma, respeitar precedentes indicaria uma conduta de boa-fé por parte do judiciário, representando um padrão de conduta a ser adotado pelos julgadores que impactaria positivamente na efetividade da jurisdição e duração razoável do processo.

Os defensores do respeito aos precedentes sustentam, ainda, que a adoção do sistema promoveria maior isonomia. Sobre isso, cabe uma pontuação: via de regra, no Direito Brasileiro, costuma-se fazer referência à isonomia sob a ótica endoprocessual, buscando assegurar às partes envolvidas a mesma "voz" dentro do processo, a fim de exercer igual influência no resultado final do julgamento. Ou seja, via de regra, a isonomia é vinculada ao contraditório. Não é a essa face da isonomia que os defensores do respeito a precedentes se referem, mas à isonomia perante as decisões judiciais, extraprocessual, ao direito de obter tratamento idêntico quando se tratar de casos que demandem a aplicação da mesma tese jurídica. Seria esse o objetivo daquele que busca o judiciário ${ }^{17}$.

\footnotetext{
${ }^{15}$ Ibid. p. 252.

${ }^{16}$ Patrícia Perrone destaca que essa confiança atua de forma mais ou menos incisiva em diversas áreas do Direito: "O stare decisis confere peso específico ao princípio da confiança em questões atinentes a direito de propriedade, contratos, responsabilidade civil, direito tributário e direito penal, por reconhecer que as partes se baseiam nos julgados referentes a tais matérias para decidir sobre o dia-a-dia de suas condutas e para estabelecer seus planejamentos mais essenciais. Por isso, nesses casos, entende-se que pode ser preferível manter uma decisão errada, a surpreender os cidadãos com uma alteração repentina, recomendando-se uma cuidadosa avaliação da surpresa a ser infligida aos postulantes. Já precedentes atinentes à matéria processual seriam mais facilmente superáveis, porque, em regra, não suscitariam o mesmo tipo de problema". Ibid. p. 254.

${ }^{17}$ CRAMER, Ronaldo. Op. cit., p. 59-61.
} 
Marinoni ressalta que apenas a observância de um procedimento justo não garante que as decisões judiciais estarão em consonância com a norma constitucional. A isonomia endoprocessual limitada à observância do contraditório não garante que o conteúdo da decisão seja isonômico, uma vez que desconsidera o conteúdo decidido e dá ênfase apenas ao procedimento. Observa o autor que existe grande lacuna ao deixar de observar uma igualdade diante das decisões judiciais ${ }^{18}$.

Pensando a decisão judicial como fruto do sistema, e não apenas de um único juiz, o autor sustenta que a racionalidade da decisão está ancorada no sistema e não apenas no discurso daquele que a proferiu. Nessa linha de entendimento, não haveria racionalidade na decisão que atribui à lei federal interpretação distinta daquele órgão ao qual a Constituição federal impõe o dever de zelar pela interpretação do direito federal.

Dito isso, Marinoni distingue o direito a um processo justo do direito a uma decisão racional e justa. O primeiro seria satisfeito por meio da observância de direitos fundamentais de natureza processual, já a legitimidade da jurisdição estaria atrelada à legitimidade da decisão ${ }^{19}$. Nas palavras do autor:

$\mathrm{Na}$ verdade, é pouco mais que absurdo pensar que o Poder Judiciário, caracterizado por um déficit de legitimidade democrática em relação ao Legislativo, possa ter várias concepções acerca de um mesmo direito fundamental, para num momento admitir e em outro negar a constitucionalidade do produto da casa habitada pelos representantes eleitos pela maioria.

Se há uma definição judicial de direito fundamental, ou mesmo acerca do significado de uma lei federal, todos devem ser tratados igualmente perante elas. A menos, é claro, que se admita que a jurisdição possa e deva conviver com vários significados de um mesmo direito fundamental ou de uma mesma lei federal, o que eliminaria qualquer possibilidade de se ter uma elaboração teórica racionalmente capaz de explicar a legitimidade de uma decisão que afirma direito fundamental e deixaria sem qualquer razão de ser as normas constitucionais que consagram as funções jurisdicionais de uniformização da interpretação da lei

\footnotetext{
${ }^{18}$ MARINONI, Luiz Guilherme. Op. cit., p. 112-113.

19 “(...) o procedimento pode ser legítimo à luz dos direitos fundatemtais processuais e, ainda assim, produzir decisão descompromissada com a substância das normas constitucionais. O contraditório legitima o procedimento, porém não se presta a garantir o ajuste da decisão ao conteúdo dos direitos fundamentais. Afirme-se, diante disso, que a legitimação da jurisdição depende da legitimidade da decisão”. Ibid.p. 112.
} 
federal e de atribuição de sentido à Constituição, além de, obviamente, violar a ideia imprescindível de igualdade perante a jurisdição $0^{20}$.

Nessa linha, o autor parece sustentar que a legitimidade da jurisdição adviria da igualdade diante das decisões judiciais, o que apenas seria possível mediante uma aplicação uniforme dos conceitos legais.

\subsection{Efeitos pragmáticos da adoção de um sistema de valorização de precedentes}

Ronaldo Cramer ressalta que o judiciário brasileiro possui cerca de 70,8 milhões de ações em curso - sendo grande parte composta de ações que tratam da mesma tese jurídica - e uma taxa de congestionamento de aproximadamente $71,4 \%{ }^{21}$. Considerando dados do IBGE, o autor informa, ainda, que essa assustadora proporção de praticamente um processo para cada três habitantes, tende a crescer ainda mais. Uma das formas de melhorar esse panorama seria através da propositura de ações coletivas, entretanto, esse tipo de ação vem sendo subutilizado, seja porque a propositura dessas ações não consegue atender à crescente demanda social, seja porque possui um procedimento complexo e, consequentemente, lento no Judiciário.

Dessa forma, o autor ressalta que não é viável que o judiciário julgue isoladamente cada uma dessas ações repetitivas, sendo extremamente interessante a implementação de um sistema de precedentes ${ }^{22}$. Apesar de saber que a adoção desse sistema não resolverá por completo o problema de abarrotamento do judiciário, o Cramer diz não ter dúvidas de que sem a adoção do sistema, a Justiça brasileira entrará em colapso.

Mas a adoção de um sistema de precedentes possui outras consequências além de proporcionar uma redução no estoque de processos e impactar positivamente na efetividade do Judiciário. Entre esses outros aspectos pragmáticos, defende-se que haveria maior racionalização na

\footnotetext{
20 Ibid. p. 114.

${ }^{21}$ CRAMER, Ronaldo. Op. cit., p. 3.

22 Ibid. p. 3-4.
} 
propositura de recursos, desestímulo à litigância, diminuição de frustrações e prejuízos com demandas infundandas e desestímulo à propositura de "aventuras jurídicas” (demandas que já se sabe contrárias ao posicionamento dos tribunais).

A partir do momento em que as partes possuem conhecimento da posição do judiciário sobre sua situação, terão plena ciência de suas vantagens e desvantagens, estando aptas a negociar objetivamente. Marinoni pontua que poderíamos pensar que a previsibilidade da solução do litígio estimularia a parte cuja pretensão está de acordo com o precedente a litigar. No entanto, sustenta que a previsibilidade permite às partes racionalizarem as vantagens e desvantagens de litigarem no judiciário. A parte mais propensa a perder utilizará argumentos para desestimular a propositura da ação, poupando tempo e gastos com o processo. Ou seja, a previsibilidade acabaria por desestimular ambas as partes a litigarem ${ }^{23}$.

Quando não há um posicionamento predominante no judiciário, em muitas situações os advogados ou mesmo os autores da ação agem como apostadores, na esperança de serem sorteados com um juiz, turma ou câmara que possa adotar posição favorável a seu pleito. O custo dessa loteria é alto ao Estado ${ }^{24}$, causando a multiplicação do número de processos, tornando a atividade jurisdicional lenta, burocrática e ocasionando a consequente perda da qualidade das decisões judiciais.

Esse cenário de completa ausência de uniformidade aumenta a inconformidade com as decisões judicias, levando ao descrédito para com a instituição, e ocasionando, ainda, uma desvalorização profunda dos juízes de primeiro grau e consequente supervalorização do segundo grau. Cappelleti ${ }^{25}$ observa que, nesse cenário, a sentença de primeiro grau não significa uma derrota e nem vitória e, por não ter execução imediata, serve

\footnotetext{
${ }^{23}$ Ibid. p. 134-135.

${ }^{24}$ Ibid. p. 134.

25 CAPPELLETTI, Mauro. Dictamen conoclastico sobre la refoma del proceso civil italiano. Proceso, ideologias, sociedad. Trad. Santiago Sentís Melendo e Tomás A. Banzhaf. Buenos Aires. EJEA. 1974. p. 278. Apud. MARINONI, Luiz Guilherme. Op. cit., p. 105.
} 
para pouco mais que nada. Afirma o referido autor que "o primeiro grau é somente uma larga fase de espera, uma extenuante e penosa antessala para e chegar à fase de apelação ou à verdadeira decisão, ao menos para a parte que tem condições econômicas de alcançá-la".

Marinoni ressalta a incoerência de posicionamento daqueles que, de um lado, defendem que o juiz de primeiro grau está livre para decidir de forma contrária aos precedentes das cortes superiores e, ao mesmo tempo, sustentam o duplo grau de jurisdição como princípio fundamental de justiça. Entende que esse seria não apenas um argumento ingênuo, mas também totalmente desprovido de razão, com o intuito de deslegitimar o poder dos juízes ${ }^{26}$. A supervalorização do duplo grau nega poder ao juiz de primeiro grau, impedindo-o de decidir isoladamente mesmo aquelas demandas em que teve contato direto com a prova e provavelmente estaria mais apto a decidir.

Seguir precedentes proporcionaria, ainda, uma racionalização dos recursos, na medida em que tornaria excepcional a admissibilidade de recursos contra decisões que foram proferidas conforme os precedentes. Entretanto, dizer que esse tipo de recurso é excepcional não significa que será impossível sua admissão, uma vez que respeitar precedentes não os transforma em imutáveis, sendo, portanto, possível a sua superação.

Marinoni ressalta que tratar casos iguais de forma diferente gera descrença na decisão e o consequente questionamento sobre sua racionalidade. Segundo o autor, tais decisões acabariam sendo vistas como "personalizadas", ou seja, associadas ou à pessoa do magistrado, ou às partes que foram beneficiadas, dificultando a credibilidade no poder judiciário $^{27}$. Nesse sentido:

A prática de se seguir precedente despersonaliza as decisões e, assim, torna mais provável que as partes derrotadas aderirão à decisão sem que a parte vencedora precise recorrer a medidas de execução. Os derrotados perceberão que a decisão

\footnotetext{
${ }^{26}$ MARINONI, Luiz Guilherme. Op. cit.,p. 105.

${ }^{27}$ Ibid. p. 135.
} 
não é meramente "contra" eles, ad hoc, mas "contra todos os demais" em situação semelhante ${ }^{28}$.

Ronaldo Cramer defende que o sistema de valorização de precedentes impactará positivamente na celeridade, duração razoável do processo e eficiência do judiciário. O uso de precedentes acelera a entrega da prestação jurisdicional, principalmente no tocante às causas repetitivas, pois, uma vez fixada a tese, a solução será aplicada aos processos que versam sobre a mesma tese jurídica. Além disso, processos que não ensejam a aplicação de precedentes (que versam sobre tese jurídica única) também serão beneficiados, uma vez que a diminuição do estoque de processos de uma forma geral permitirá que sejam julgados mais rapidamente ${ }^{29}$ e que os julgadores elaborem decisões com maior qualidade.

Com a entrada em vigor do CPC/2015, o sistema de valorização de precedentes pretende tornar-se realidade fática, o que demandará não apenas uma modificação na postura dos operadores do direito, mas também uma mudança do ensino jurídico como um todo. Cramer observa que, na maior parte das faculdades de Direito, prevalecem as aulas expositivas típicas do Civil Law, onde a norma jurídica é compreendida de forma hipotética, partindo apenas do texto da lei. O autor não propõe um abandono a esse sistema, mas uma mescla dessas aulas expositivas com discussões de casos, a fim de permitir um melhor aprendizado sobre o tema. Ressalta, ainda, a necessidade de mudança da doutrina nas diversas áreas de direito material, para que deixem de fazer referências apenas à ementa dos julgados e passem a fazer análise de sua fundamentação a fim de interpretar a ratio decidendi ${ }^{30}$.

\footnotetext{
28 SUMMERS, Robert S. Precedent in the United States (New York State). In: MacCormick, Neil; Summers Robert S. Interpreting precedents:a comparative study. London: Darthmouth, 1997. p. 382. Apud. MARINONI, Luiz Guilherme. Op. cit., p. 136.

${ }^{29}$ CRAMER, Ronaldo. Op. cit., p. 61-62.

${ }^{30}$ Ibid. p. 205-207.
} 


\subsection{Argumentos contrários à adoção de um sistema de valorização de precedentes}

Os principais argumentos contrários à força vinculante dos precedentes judiciais giram em torno do engessamento do judiciário. Entretanto, Marinoni defende que tal crítica pressupõe erroneamente que o precedente, uma vez fixado, não poderia ser alterado, o que não é factível. Nem mais no berço do Common Law, em que a força dos precedentes um dia chegou a ser absoluta, insiste-se na imutabilidade do precedente ${ }^{31}$.

No Direito americano sempre houve uma preocupação com a possível restrição ao desenvolvimento do direito, com a perpetuação de erros e injustiças e com o surgimento de novos fatos e valores. Por isso, a doutrina e a jurisprudência estadunidenses reconhecem a possibilidade de revogação de precedentes em casos excepcionais e com a devida justificativa.

Nesse sentido, Ronaldo Cramer alerta que estabilidade e imutabilidade não são sinônimos, e que o precedente deve permanecer vigente até que haja justo motivo para modificá-lo. Dessa forma, "tal noção de estabilidade presume a possibilidade de adaptação ou mudança do precedente $^{32}$ ".

Há os que argumentam que a força obrigatória dos precedentes poderia ser vista como óbice ao tratamento diferenciado daquelas situações que não deveriam se enquadrar na aplicação do precedente em virtude de suas peculiaridades, ou seja, impediria que determinadas situações recebessem solução diversa do precedente.

Ocorre que, como bem assevera Marinoni, "respeitar precedentes não redunda - jamais redundou - numa obrigação de aplicá-los de forma

\footnotetext{
${ }^{31}$ Em 1966, a House of Lords afirmou que poderia deixar de observar seus precedentes, buscando evitar injustiças no caso concreto e desde que o precedente representasse restrição ao devido desenvolvimento do direito. MARINONI, Luiz Guilherme. Op. cit., p. 139-140.

32 CRAMER, Ronaldo. Op. cit, p. 64.
} 
irrefletida ${ }^{33}$ " e ressalta que devem ser considerarados prejuízos que podem decorrer da inadequada utilização do precedente.

Para ser racionalmente utilizado, o precedente não pode ser visto apenas em abstrato. A ideia de precedente não impede que casos distintos devam receber tratamento diverso. Não se pode rotular um instituto por seu mal uso, pois assim como um precedente pode ser mal aplicado, uma lei não está livre de incorrer no mesmo erro.

Pode-se argumentar, ainda, que obrigar um juiz a cumprir um precedente seria violar sua independência. Nesse entender, o juiz apenas seria independente se fosse livre para decidir de forma contrária às cortes supremas. Entretanto, esse argumento parece desconsiderar que o judiciário é um sistema, e, como tal, deve funcionar de forma coerente. Quando a Constituição estabelece independência do judiciário, refere-se à sua autonomia em relação aos demais poderes e, no que diz respeito à figura do juiz, atribui-lhe uma independência no sentido de não permitir que sofra retaliações e exerça livremente sua atividade.

Nas lições de Marinoni:

É preciso não confundir independência do juiz com ausência de unidade, sob pena de, ao invés de se ter um sistema que racional e isonomicamente distribui justiça, ter-se algo que, mais do que falhar aos fins que se destina, beira a um manicômio, onde vozes irremediavelmente contrastantes, de forma ilógica e improducente se digladiam ${ }^{34}$ ".

Mais adiante, o autor continua:

"Deveria ser evidente, mas não é, que o cargo de juiz não existe para que aquele que o ocupa possa proferir a sua decisão, mas para que possa colaborar com a prestação jurisdicional - para o que a decisão, em contraste ao precedente, nada representa, constituindo, em verdade, um desserviço ${ }^{35}$ ".

Aqueles que sustentam que vincular o juiz ao passado seria um atentado à sua liberdade não conseguem compreender que a decisão é resultado de um sistema, e não algo construído de forma individualizada

\footnotetext{
${ }^{33}$ MARINONI, Luiz Guilherme. Op. cit., p. 143.

${ }^{34}$ Ibid. p. 149.

${ }^{35}$ Ibid. p. 149-150.
} 
por um sujeito que deseja valer sua vontade sobre a do próprio sistema em que faz parte.

Ainda nas pontuações de Marinoni, o autor defende que não respeitar precedentes estaria próximo de uma afronta ao poder e à coerência da ordem jurídica ${ }^{36}$. Quando a Constituição determina que cabe ao STF dar a última palavra sobre a interpretação da Constituição e que cabe ao STJ dar a última palavra a respeito da lei federal, questiona-se se seria coerente permitir que um juiz escolha livremente contrariar as decisões de tais tribunais sem uma fundamentação adequada.

Outro argumento a ser levantado contra a adoção de um sistema de precedentes seria uma possível violação à separação de poderes, uma vez que o judiciário estaria legislando. Entretanto, sabe-se que a atividade jurisdicional não se limita a aplicar os conceitos legais de forma automática, e, mais do que isso, sabe-se que o texto legal não é suficiente para abarcar todas as hipóteses cotidianas. Por isso, defendores do respeito aos precedentes não negam que ao estabelecer um precedente o judiciário cria norma que deverá ser seguida em casos futuros. Mas isso não representa, de forma alguma, uma licença para que o juiz não cumpra a lei ${ }^{37}$ ou extrapole os limites estabelecidos pela moldura legislativa. $O$ objetivo é, principalmente, que haja uma interpretação uniforme do texto legal por parte do Judiciário.

\footnotetext{
36 “(...) é óbvio que o juiz ou o tribunal não decide para si, mas para o jurisdicionado. Por isso, pouco deve importar se o juiz tem posição pessoal, acerca da questão de direito, que difere das Cortes Supremas. O que realmente deve ter significado é a irracionalidade de o Judicário decidir questões iguais de forma diferente. O juiz que contraria a "última palavra" do Poder de que faz parte está muito longe do exercício de qualquer liberdade, estando muito mais perto da prática de um ato de afronta ao Poder e à coerência da ordem jurídica". Ibid. p. 53.

${ }^{37}$ Cabe uma reflexão se o juiz que controla a constitucionalidade da lei estaria submetido a ela, ou se esse papel negaria a ideia de supremacia do legislativo. Marinoni é adepto dessa posição e entende que quando o juiz supre uma omissão ou quando utiliza técnicas de interpretação conforme a Constituição ou de declaração parcial de nulidade sem redução de texto estaria conferindo à lei interpretação diversa daquela estabelecida pelo legislativo. MARINONI, Op. cit., p. 59.
} 


\subsection{Insuficiência do texto legal e a necessidade de respeito aos precedentes como forma de controle das decisões judiciais}

A adoção técnica das cláusulas abertas pelo legislativo se difundiu a partir dos anos 40 do século XX. Diante do obsoletismo de leis muito específicas, o sistema brasileiro optou por uma técnica que utiliza termos indeterminados, conferindo aos juízes uma maior elasticidade dos conceitos legais. Dito isso, podemos concluir que essa técnica permite que sejam proferidas decisões com elementos que não estão precisos no texto legal.

Marinoni expõe que essa mudança de técnica legislativa exige do magistrado um raciocínio muito mais elaborado e sofisticado, tornando fundamental algum tipo de controle das decisões para que haja um mínimo de isonomia e previsibilidade. Esse seria um indício de que a expectativa do jurisdicionado em relação à lei foi transferida para a decisão judicial ${ }^{38}$.

Nas palavras do autor: "se o juiz se vale da cláusula geral para chegar na norma adequada à regulação do caso concreto, a cláusula geral é norma legislativa incompleta e a decisão é a verdadeira norma jurídica do caso" 39 .

É ingênuo defender que o texto normativo comporta apenas um único significado e que a tarefa do intérprete se limitaria apenas à aplicação da norma. Entretanto, Marinoni destaca que esse problema da pluralidade de interpretações da lei não é apenas do judiciário, mas da própria redação da do texto legal ${ }^{40}$.

\footnotetext{
38 A passagem da técnica casuística, em que a aplicação da norma se dá por subsunção, para a técnica das cláusulas gerais, em face da qual se exige um raciocínio judicial muito mais complexo e sofisticado, faz ver a necessidade de insistir na igualdade perante as decisões judiciais. Quando se tem consciência teórica de que a decisão nem sempre é resultado de critérios previamente normatizados, mas pode constituir norma fundada em elementos que não estão presentes na legislação, não há como deixar de perceber que as expectativas que recaíam na lei transferem-se para a decisão judicial. A segurança jurídica passa a estar estritamente vinculada à decisão - essa é responsável pela previsibilidade em relação ao direito, e, portanto, tem de contar com estabilidade. MARINONI, Luiz Guilherme. Op. Cit, p., 117.

${ }^{39}$ Ibid. p. 117.

$40 \mathrm{O}$ problema da interpretação da lei não está propriamente no poder que se confere ao juiz, mas na própria dicção da norma legal. Embora o objetivo da limitação da decisão à letra da lei seja o de conter o arbítrio do juiz, não há dúvida que a compreensão da lei, e, portanto, o subjetivismo, varia
} 
É verdade que houve uma ação do legislador ao elaborar o texto, mas os termos são tão amplos que o juiz quase não se vê condicionado pela formulação legislativa. $\mathrm{O}$ que a norma significa depende do uso que o juiz atribui a ela no caso concreto, sendo esse o direito factual (law in fact), apesar de não teórico (law in theory $)^{41}$.

A possibilidade de suprir uma omissão legislativa, de ponderar um eventual choque entre dispositivos legais e a multiplicação de conceitos indeterminados parecem demonstrar que o julgador está distante de ser concebido como mero aplicador da lei. Além disso, é importante notar que, por mais preciso que seja o texto legal, ele é insuficiente para regular todas as situações passíveis de ocorrer em casos concretos. Frederick Schauer defende que, independentemente da vagueza da linguagem, quando se opta por adotar um sistema de regras, necessariamente aceita-se que estas são potencialmente sobre ou subinclusivas ${ }^{42}$.

Dito isso, parece impossível que o legislador preveja todas as situações concretas, razão pela qual, por mais determinado que seja o núcleo de uma lei, isso não significa que o juiz nunca irá se deparar ao menos com hipóteses de sobre ou subinclusão, em que o texto legal não será suficiente para delimitar o alcance da norma. Nas lições de Marinoni:

na medida em que a letra da norma abre maior ou menor espaço para o magistrado atuar na definição do significado normativo. Entende-se, em vista disso, que o subjetivismo do juiz é um dado; o que importa, diante da construção da decisão é o texto legal. A lei é interpretada - e não meramente aplicada - não apenas porque o juiz inevitavelmente deve compreendê-la, mas especialmente porque o seu significado precisa ser apreendido e deduzido. MARINONI, Luiz Guilherme. Op. Cit., p. 115.

41 MERRYMANN, John Henry; Pérez-Perdomo, Rogelio. The civil law tradition: an introduction to the legal systems of Europe and Latin America. Stanford: Stanford University Press. 2007. Apud. MARINONI, Op. cit., p. 65.

42 Os fenômenos da sobre ou subinclusão são diferentes da vagueza. Mesmo que com núcleo normativo forte, regras são potencialmente sobre ou subinclusivas. Noel Struchiner esclarece em nota de rodapé que "o surgimento de um caso de penumbra é diferente do surgimento de um caso não antecipado que cai dentro do núcleo de significado dos conceitos empregados na regra, mas fora dos seus propósitos subjacentes. A caracterização de uma regra como sendo sobre ou subinclusiva pressipõe a sua determinação enquanto a textura aberta da linguagem representa a possiblidade constante da nossa linguagem se mostrar indeterminada". STRUCHINER, Noel. O direito como um campo de escolhas: Por uma leitura das regras prescritivas como relações. In: José Rodrigo Rodriguez; Carlos Eduardo Batalha da Silva e Costa; Samuel Rodrigues Barbosa. (Org.). Nas Fronteiras do Formalismo. 1ed.São Paulo: Saraiva, 2010, p.111. 
(...) [a técnica das cláusulas gerais] não só faz ruir a ideia de completude dos compêndios legislativos, definidos exclusivamente a partir da técnica casuística, como demonstra a isuficiência da lei, aplicada à base de subsunção, para a solução dos variados casos litigiosos concretos. Com isso, inquestionavelmente, confere maior subjetividade ao juiz, dando-lhe poder para construir a decisão a partir de elementos que não estão presentes no texto normativo ${ }^{43}$.

Ao defender um sistema de precedentes, não se nega a importância fundamental das leis para a tomada da decisão jurídica, mas, ao contrário, defende-se que a decisão judicial deve justamente ser tomada conforme a moldura estabelecida pela lei ${ }^{44}$. Isso não significa que nada deva ficar a cargo de intérprete, mas também não significa que ele possa se ver livre das amarras legais. "A função das cláusulas gerais não é permitir uma inflação de normas jurídicas para um mesmo caso, mas o estabelecimento de normas de caráter geral ${ }^{" 45}$.

Infelizmente, uma análise da prática decisória dos tribunais demonstra ausência de uniformidade na interpretação do Direito, indicando que, não raras vezes os julgadores se veem desvinculados das amarras legais e, menos ainda, se veem vinculados às suas próprias decisões pretéritas, ou às do tribunal ao qual fazem parte, ou às das Cortes superiores. Por isso, além da adoção de um sistema de precedentes para conferir uma interpretação uniforme ao texto legal, é imprescindível o estabelecimento de critérios para exercer um controle sobre as decisões judiciais ${ }^{46}$.

Como observa Frederick Schauer:

(...) a adoção do stare decisis (assim como de qualquer sistema baseado em regras) pressupõe uma redução da sensibilidade dos magistrados para as particularidades dos casos. Por isso, ao mesmo tempo em que mitiga o risco de decisões contraditórias e erradas, diminui a perspectiva de alcançarem soluções

\footnotetext{
${ }^{43}$ MARINONI, Luiz Guilherme. Op. cit., p. 117.

44 "No entanto, num sistema de precedentes adotado pelo Civil Law, a norma não é forjada a partir da vontade do julgador ou da observação dos costumes da sociedade, mas com base em texto normativo, que, por sua vez, ou é a própria lei, ou não pode ser contrário à lei”. CRAMER, Ronaldo. Op. cit., p. 65.

${ }^{45}$ MARINONI, Luiz Guilherme. Op. cit., p. 118.

${ }^{46}$ Ibid. p. 118-119.
} 
ótimas, do ponto de vista da justiça do caso concreto, limitando tanto o mau quanto o bom juiz ${ }^{47}$.

Nessa linha, parece que a escolha que se faz para a adoção de um sistema de valorização de precedentes se assemelha à escolha que se faz quando se opta por um sistema de regras ao invés de um sistema particularista: aceita-se a produção de resultados subótimos para que se busque uma maior segurança, previsibilidade, isonomia e efetividade.

Dito isso, parece ser possível sustentar que precedentes poderiam funcionar como regras, de modo a representarem uma estratégia para evitar vieses aos quais os julgadores estariam submetidos no momento da tomada da decisão jurídica - principalmente se esses precedentes, evidentemente, não forem criados de forma enviesada. Considero esse tema especialmente interessante no que diz respeito ao estudo de precedentes, entretanto, não há espaço no presente trabalho para essa análise, que poderá ser objeto de mais estudo e aprofundamento no futuro.

Passaremos, agora, a analisar os dispositivos trazidos pelo CPC/2015 que balizam a discussão a respeito do sistema de precedentes.

47 SCHAUER, Frederick. Rules, the Rule of Law, and the Constitution. Constitutional Commentary, Minneapolis, vol. 6, 1989, p. 69; SCHAUER, Frederick. Precedent. Stanford Law Review, Palo Alto, v. 39, Feb. 1987, p. 571-605. Apud. MELlO, Patrícia Perrone Campos, Op. cit., p. 68. 


\section{Os precedentes no Novo código de Processo Civil}

A prática brasileira demonstra que os precedentes sequer vêm sendo tratados como persuasivos. Luiz Guilherme Marinoni considera que o fato de juízes trocarem livremente o sinal de suas decisões e não respeitarem os julgados de Cortes superiores representa uma patologia ${ }^{48}$ que dominou nosso sistema.

O CPC/2015, em vigor desde março deste ano, tem o objetivo de concretizar um sistema de valorização de precedentes até então inexistente no Brasil. Tal objetivo era evidente já na exposição de motivos do anteprojeto elaborado pela comissão de juristas e apresentado ao Senado Federal. Como exemplo, podemos listar as seguintes passagens:

O novo Código prestigia o princípio da segurança jurídica, obviamente de índole constitucional, pois que se hospeda nas dobras do Estado Democrático de Direito e visa a proteger e a preservar as justas expectativas das pessoas.

(...)

Se, por um lado, o princípio do livre convencimento motivado é garantia de julgamentos independentes e justos, e neste sentido mereceu ser prestigiado pelo novo Código, por outro, compreendido em seu mais estendido alcance, acaba por conduzir a distorções do princípio da legalidade e à própria idéia, antes mencionada, de Estado Democrático de Direito. A dispersão excessiva da jurisprudência produz intranqüilidade social e descrédito do Poder Judiciário . Se todos têm que agir em conformidade com a lei, ter-se-ia, ipso facto, respeitada a isonomia. Essa relação de causalidade, todavia, fica comprometida como decorrência do desvirtuamento da liberdade que tem o juiz de decidir com base em seu entendimento sobre o sentido real da norma ${ }^{49}$.

$\mathrm{O}$ art. $847^{50}$ do anteprojeto apresentado ao Senado não mencionava expressamente a palavra "precedente", mas determinava a uniformização e

\footnotetext{
48 "Embora as decisões, no sistema brasileiro, troquem livremente de sinal e não respeitem os julgados das Cortes superiores, deve-se as sinalar que is so constitui uma patologia ou um equívoco que, infelizmente, arraigou-se em nossa tradição jurídica. MARINONI, Luiz Guilherme. Op. cit., p. 93.

49 Trecho extraído do Anteprojeto do Novo Código de Proceso Civil, páginas 17 e 19. Disponível em: http://www.senado.gov.br/senado/novocpc/pdf/Anteprojeto.pdf. Acesso em: 20/10/2016.

50 Art. 847. Os tribunais velarão pela uniformização e pela estabilidade da jurisprudência, observando-se o seguinte:

I - sempre que possível, na forma e segundo as condições fixadas no regimento interno, deverão editar enunciados correspondentes à súmula da jurisprudência dominante;

II - os órgãos fracionários seguirão a orientação do plenário, do órgão especial ou dos órgãos fracionários superiores aos quais es tiverem vinculados, nesta ordem;
} 
estabilidade da jurisprudência. Ronaldo Cramer entende que o dispositivo parecia criar uma jurisprudência vinculante dos tribunais superiores (jurisprudência vertical) e uma vinculação à jurisprudência do próprio tribunal (jurisprudência horizontal) ${ }^{51}$.

Após a aprovação pelo Senado, conforme relatório do Senador Válter Pereira ${ }^{52}$, o dispositivo manteve quase a mesma redação. Entretanto, foi feita uma pequena mudança, mas com grandes consequências. Foi incluída a locução "em princípio", o que descaracterizou o propósito original e fez com que a jurisprudência deixasse de ser vinculante. A redação do caput do artigo passou a ser: "os tribunais, em princípio, velarão pela uniformização e pela estabilidade da jurisprudência...".

Ao chegar na Câmara, a questão sofreu profunda alteração ${ }^{53}$. Foi criado um capítulo específico sobre precedentes e, segundo o relatório do deputado Paulo Teixeira, ficava claro que a mudança tinha o intuito de manter o sistema de precedentes vinculantes aprovado no Senado, bem como aperfeiçoá-lo, de modo a deixar explícita a eficácia vinculante dos precedentes e promover maior segurança jurídica, isonomia e confiança.

Ronaldo Cramer entende que esse projeto aprovado na Câmara conferiu o melhor tratamento à matéria, uma vez que expressamente se referiu aos precedentes como vinculantes ${ }^{54}$. Entretanto, quando voltou ao Senado para análise das modificações, o tema foi eliminado o capítulo que

III - a jurisprudência pacificada de qualquer tribunal deve orientar as decisões de todos os órgãos a ele vinculados;

IV - a jurisprudência do Supremo Tribunal Federal e dos tribunais superiores deve nortear as decisões de todos os tribunais e juízos singulares do país, de modo a concretizar plenamente os princípios da legalidade e da isonomia;

V - na hipótese de alteração da jurisprudência dominante do Supremo Tribunal Federal e dos tribunais superiores ou daquela oriunda de julga- mento de casos repetitivos, pode haver modulação dos efeitos da alteração no interesse social e no da segurança jurídica.

$\S 1^{\circ}$ A mudança de entendimento sedimentado observará a necessidade de fundamentação adequada e especifica, considerando o imperativo de estabilidade das relações jurídicas.

$\S 2^{\circ}$ Os regimentos internos preverão formas de revisão da jurisprudência em procedimento autônomo, franqueando-se inclusive a realização de audiências públicas e a participação de pessoas, órgãos ou entidades que possam contribuir para a elucidação da matéria"

51 CRAMER, Ronaldo. Precedentes judiciais: teoria e dinâmica. Rio de Janeiro: Forense. 2016. p. 176-177.

52 Ibid.

53 Ibid. p. 178.

${ }^{54}$ Idib. P. 179. 
tratava especificamente dos precedentes e recolocado na parte que trata de processos nos tribunais, dando origem à redação atual do artigo $927^{55}$.

\subsection{0 art. 927 e suas possíveis interpretações}

Argumentando principalmente a redação imperativa do dispositivo e a vontade do legislador, Ronaldo Cramer ${ }^{56}$, Fredie Didier Jr., Paula Sarno Braga e Rafael de Alexandria ${ }^{57}$, entre outros, sustentam que o art. 927 prevê um rol de precedentes vinculantes ${ }^{58}$. Entretanto, essa entendimento não é unânime.

Uma segunda corrente interpreta que o art. 927 não traz um rol de precedentes vinculantes, uma vez que não prevê a possibilidade de interposição de reclamação para assegurar a aplicação de todos os provimentos contidos no dispositivo. Dessa forma, apenas os três primeiros incisos representariam precedentes vinculantes, uma vez que apenas estes estariam listados no art. 988 como passíveis de reclamação. Essa corrente é encampada entre outros por Luís Roberto Barroso e Patrícia Perrone Campos Mello. Nesse sentido, dispõem os autores:

O cabimento de reclamação é essencial, em nosso sistema, para a efetividade do respeito ao precedente. Não há, aqui, tradição neste sentido. Ao contrário, há mesmo alguma resistência em aceitar a ampliação dos precedentes vinculantes, por se considerar que estes interferem indevidamente na independência e no livre convencimento dos juízes. $\mathrm{E}$ a correção das decisões que violam os precedentes judiciais pelo sistema recursal tradicional pode levar muitos anos. Consequentemente, só é possível falar em eficácia normativa forte, por ora, para aqueles casos em que é cabível a reclamação ${ }^{59}$.

(...)

Por outro lado, são dotados de eficácia normativa em sentido forte: as súmulas vinculantes, os julgados produzidos em controle concentrado da constitucionalidade, os acórdãos proferidos em julgamento com repercussão geral ou em recurso extraordinário ou especial repetitivo, as orientações oriundas do julgamento de incidente de resolução de demanda repetitiva e de incidente de

\footnotetext{
55 Ibid. p. 181-183.

56 Ibid. 188.

57 DIDIER JR., Fredie; BRAGA, Paula Sarno; OLIVEIRA, Rafael Alexandria de. Op. cit., p. 474.

58 Nesse sentido dispõe o enunciado 170 do Fórum Permanente de Processualistas Civis: "As decisões e precedentes previstos nos incisos do caput do art. 927 são vinculantes aos órgãos jurisdicionais a eles submetidos".

59 BARROSO, Luís Roberto; MELLO, Patrícia Perrone Campos. Trabalhando com uma nova lógica: a ascensão dos precedentes no direito brasileiro. p. 13. Disponível em: http://s.conjur.com.br/dl/artigo-trabalhando-logica-ascensao.pdf. Acess ado em 10/11/2016.
} 
assunção de competência. $O$ desrespeito a estes precedentes enseja a sua cassação, por meio de reclamação, junto à corte que o proferiu, nos termos do art. 988 do $\mathrm{CPC}^{60}$.

Outra corrente, defendida por Alexandre Câmara ${ }^{61}$, entende que apenas a determinação imperativa do caput do art. 927 não seria suficiente para conferir eficácia vinculante a todos provimentos do dispositivo. Segundo o autor, precedentes vinculantes são aqueles que possuem tal eficácia expressamente determinada em outro dispositivo legal. Dessa forma, seriam vinculantes as decisões em controle concentrado de constitucionalidade, as súmulas vinculantes e as decisões nos incidentes de assunção de competência e de casos repetitivos. Os demais provimentos teriam eficácia meramente persuasiva, gerando um dever jurídico para que juízes e tribunais observem tais precedentes em suas decisões.

Há, ainda, uma quarta corrente que entende que o dispositivo seria inconstitucional, uma vez que apenas a Constituição poderia conceder eficácia vinculante a um precedente. Essa corrente é defendida, entre outros, por Cruz e Tucci62, Nelson Nery Jr. e Rosa Maria de Andrade Nery $^{63}$ e Cassio Scarpinella Bueno ${ }^{64}$.

Diante de tantas divergências doutrinárias, podemos questionar se não teria sido mais prudente que a lei tivesse sido mais específica e clara sobre o tema, direcionando melhor a interpretação do dispositivo. Mas, em resumo, podemos concluir que salvo da tese que entende pela inconstitucionalidade do dispositivo, as três outras sustentam que ao menos os três primeiros incisos do art. 927 seriam vinculantes, seja pela redação imperativa do dispositivo, seja porque são passíveis de reclamação, seja porque encontram amparo legal em outro dispositivo que lhe atribua eficácia vinculante. Além disso, mesmo aqueles que entendem que os

\footnotetext{
${ }^{60}$ Ibid. p. 16.

${ }^{61}$ CÂMARA, Alexandre Freitas. O novo processo civil brasileiro. São Paulo: Atlas, 2015, p. 434.

62 "O regime do precedente judicial no novo CPC". Precedentes. Fredie Didier Jr. et al. (coord.). Salvador: Juspodivm, 2015, p. 454. Apud. CRAMER, Ronaldo. Op. cit, 186.

${ }^{63}$ Comentários ao Código de Processo Civil. São Paulo: Revista dos Tribunais, 2015. p. 1.837. Apud. CRAMER, Ronaldo. Op. cit., p. 186.

${ }^{64}$ Manual de direito processual civil. São Paulo: Saraiva, 2015, p. 538. Apud. CRAMER, Ronaldo. Op. cit., p. 186.
} 
demais incisos (IV e V) não seriam vinculantes, não negam que deveriam, ao menos, ser levados em conta pelo magistrado no momento de decidir.

Didier Jr., Braga e Oliveira defendem que os juízes e tribunais devem conhecer de ofício os precedentes estabelecidos pelo art. 927 sob pena de omissão e negação da justiça. Os autores defendem uma interpretação ampliativa da regra contida no art. 1.022, PU, I do CPC/2015, que estabelece que incorre em omissão e negação da justiça a decisão que deixe de se manifestar sobre tese firmada em julgamentos de casos repetitivos ou em incidente de assunção de competência aplicável ao caso sob julgamento ${ }^{65}$.

Marinoni parece entender que se trata de vício mais grave ao sustentar que o fato de julgadores não articularem os precedentes persuasivos invocados pelos advogados das partes representaria um vício tão grave quanto o descaso em relação a uma prova, devendo gerar nulidade da decisão ${ }^{66}$.

Mas, apesar da divergência quanto à interpretação do art. 927, os arts. 489, $\S 1^{\circ}$ e 926 possuem clara prescrição ao afirmar a importância da devida fundamentação das decisões e ao determinar que os tribunais devem uniformizar a jurisprudência, tornando-a íntegra, estável e coerente. Analisaremos, abaixo, a importância desses dispositivos para a defesa de um sistema de precedentes.

\subsection{O dever de motivação das decisões judiciais}

O art. 93, IX da CRFB/88 estabelece que toda decisão judicial deve ser fundamentada sob pena de nulidade. Buscando conferir maior qualidade a essa determinação, que possui especial importância quando se fala em

\footnotetext{
65 Os autores defendem que esse dispositivo deve ser aplicado extensivamente para a decisão que deixe de considerar qualquer dos incisos do art. 927. DIDIER JR., Fredie; BRAGA, Paula Sarno; OLIVEIRA, Rafael Alexandria de. Op. cit., p. 469.

66 "O precedente, quando persuasivo, constitui um argumento da parte, e, por isso mesmo, não pode ser adotado ou rejeitado sem a devida fundamentação. Aliás, a desconsideraçãodo precedete é tão grave quanto o descaso em relação à prova, devendo gerar a nulidade da decisão". MARINONI, Luiz Guilherme. Op cit., p. 93.
} 
eficácia normativa de precedentes, o CPC/2015 definiu melhor o que seria uma decisão bem fundamentada.

Nesse sentido, dispõe o $\$ 1^{\circ}$ do art. 489 do CPC/2015:

"§ 1o Não se considera fundamentada qualquer decisão judicial, seja ela interlocutória, sentença ou acórdão, que:

I - se limitar à indicação, à reprodução ou à paráfrase de ato normativo, sem explicar sua relação com a causa ou a questão decidida;

II - empregar conceitos jurídicos indeterminados, sem explicar o motivo concreto de sua incidência no caso;

III - invocar motivos que se prestariam a justificar qualquer outra decisão;

IV - não enfrentar todos os argumentos deduzidos no processo capazes de, em tese, infirmar a conclusão adotada pelo julgador;

V - se limitar a invocar precedente ou enunciado de súmula, sem identificar seus fundamentos determinantes nem demonstrar que o caso sob julgamento se ajusta àqueles fundamentos;

VI - deixar de seguir enunciado de súmula, jurisprudência ou precedente invocado pela parte, sem demonstrar a existência de distinção no caso em julgamento ou a superação do entendimento".

Nos termos do dispositivo, para que seja adequadamente fundamentada, a decisão deve identificar as questões de fato essenciais para a solução do caso, e ser clara ao explicitar a tese jurídica adotada para a conclusão. Não se considerará fundamentada uma decisão que apenas transcreve dispositivo de lei ou invoca a ementa de um julgado como fundamentação ${ }^{67}$.

A função extraprocessual da fundamentação ocorre quando, além de servir à justificação daquela decisão específica, serve como modelo de conduta para os indivíduos que não fazem parte do processo e invocarão aquela decisão como precedente, servindo, ainda, como uma forma de controle das decisões judiciais.

Ronaldo Cramer ressalta que, no momento de decidir, o julgador deverá criar duas fundamentações: uma para a solução do caso concreto (discurso interno) e uma para a formulação da norma (discurso externo ${ }^{68}$. A primeira representaria a necessidade de o julgado expor as razões

\footnotetext{
${ }^{67}$ DIDIER JR., Fredie; BRAGA, Paula Sarno; OLIVEIRA, Rafael Alexandria de. Op. cit., p. 484.

${ }^{68}$ A norma do precedente encontra-se na fundamentação, não se confundindo, no entanto, com ela. A extração da tese jurídica, que configurará a norma do precedente, não constitui uma tarefa fácil e se tornará impossível, se o julgado não for minimamente claro sobre o entendimento que edificando para solucionar o caso concreto. CRAMER, Ronaldo. Precedentes judiciais: teoria e dinâmica. Rio de Janeiro: Forense. 2016. p. 136
} 
suficientes para a solução adotada, e a segunda, por sua vez, representa a necessidade de elaboração da norma do precedente, devendo conter os argumentos que expliquem os motivos considerados pela decisão para chegar à norma formulada, viabilizando, assim, a integridade e coerência da jurisprudência, propiciando o controle das decisões judiciais e facilitando a identificação da norma do precedente.

Entretanto, já sob a vigência do CPC/2015, observa-se que o dispositivo não vem sofrendo os efeitos esperados. Recentemente, o Min. Luís Roberto Barroso, defensor do sistema de valorização de precedentes, proferiu a seguinte decisão Recurso Extraordinário nº 992.29969:

Trata-se de agravo cujo objeto é decisão que negou seguimento ao recurso extraordinário.

A decisão agravada está correta e alinhada aos precedentes firmados por esta Corte. Dante do exposto, com base no art. $21, \S 1^{\circ}$ do RI/STF, nego seguimento ao recurso.

Publique-se.

Brasilia, 15 de setembro de 2016.

Ministro LUÍS ROBERTO BARROSO - Relator.

Sabe-se que, quando a decisão reitera a aplicação de um precedente, o ônus argumentativo do julgador é menor. Entretanto, à luz do CPC/2015, não parece que a decisão acima esteja suficientemente fundamentada. $\mathrm{O}$ inciso $\mathrm{V}$ do $\$ 1^{\circ}$ do art. 489 do $\mathrm{CPC} / 2015$ dispõe que não se considera fundamentada qualquer deisão que "se limitar a invocar precedente ou enunciado de súmula, sem identificar seus fundamentos determinantes nem demonstrar que o caso sob julgamento se ajusta àqueles fundamentos".

De acordo com Marinoni:

Ao considerar a sentença destituída de fundamentação e, portanto, nula, o Código confere grande importância ao sistema de precedentes, proibindo duas práticas que vinham se tornando costumeiras no direito brasileiro: i) o simples registro de acórdãos da Suprema Corte como fundamento para decidir e ii) a não

69 Em artigo recente sobre essa decisão, Lênio Streck observa que: "O que preocupa é a falta de fundamentação na decisão que negou seguimento ao agravo. Preocupa-me o conjunto de ilegalidades. Sequer é possível saber a matéria versada no recurso, pois o ministro Barroso limitou-se a dizer que a decisão agravada estaria correta e alinhada aos precedentes firmados pelo Supremo. Porém, quais são esses precedentes? Por que a decisão está correta? A menção aos "precedentes" da corte, que sequer são referidos na decisão, supre as exigências do $\S 1^{\circ}$ do artigo 489 do Código de Processo Civil Brasileiro? STRECK, Lênio. Precedentes? Decisão de 4 linhas do STF contém três violações ao CPC. Disponível em: http://www.conjur.com.br/2016-nov10/senso-incomum-precedentes-decisao-linhas-stf-contem-tres-violacoes-cpc. Acesso em $24 / 11 / 2016$. 
consideração de acórdão de Suprema Corte invocado pela parte. Em termos de adequada fundamentação, é certo que o mero registro de decisão de Corte Suprema sem a demonstração de que a decisão é precedente e que esse se adapta à solução do caso, é insuficiente. Também não é possível que o juiz, diante dos argumentos da parte e do caso a ser solucionado, possa simplesmente ignorar decisão de Corte Suprema, deixando de demostrar que a decisão não tem características de precedente ou que esse não se aplica ao caso sob julgamento ${ }^{70}$.

Para que o julgador possa solucionar um caso aplicando um precedente, deve, necessariamente, demonstrar que o presente caso está inserido na questão de direito resolvida pela ratio. Não quer dizer que os casos devem ser absolutamente iguais faticamente, o que é praticamente impossível, mas que a questão de direito resolvida na ratio esteja presente no caso sob julgamento. Quando a questão de direito se apresentar de forma diferente em virtude de situações fáticas peculiares ao caso, a aplicação da ratio deverá ser rejeitada ${ }^{71}$.

Não há dúvidas de que muitos serão os obstáculos para a efetivação da nova lei, mas espera-se que haja ao menos um empenho dos julgadores em fundamentar adequadamente suas decisões.

Sabemos que esse dever de motivação se faz especialmente importante quando for o caso de afastar a aplicação ou de superar um precedente. A distinção, ou distinguishing, não pode ser feita apenas porque o julgador não deseja aplicar um precedente com o qual não concorda. Uma forma de minimizar essa possibilidade seria exatamente essa exigência de uma carga argumentativa forte ${ }^{72}$ como forma de controle da conduta do juiz quando deixar de aplicar o precedente.

O julgador não pode deixar de considerar um precedente invocado pela parte sem demonstrar que ele não deve ser aplicado àquele caso específico, pois, do mesmo modo que não pode deixar de considerar um fundamento de direito alegado pela parte quando este for relevante para a resolução do caso, não pode ignorar um precedente invocado quando este puder interferir no resultado.

\footnotetext{
70 MARINONI, Luiz Guilherme. Op. cit., p. 338.

${ }^{71}$ Ibid. p. 339.

72 Trata-se de uma fundamentação qualificada, prevista no Art. 489, §1 ${ }^{\circ}$, VI do CPC/2015.
} 
Sabemos que dever de motivação adequada não significa que o juiz nunca irá afastar a aplicação de um precedente, ou que nunca intepretará restritivamente uma ratio decidendi de maneira a retirar o caso atual de seu campo de aplicação. Entretanto, permite às partes um maior controle da decisão em eventual recurso interposto.

\subsection{Deveres gerais dos tribunais relacionados ao sistema de precedentes}

Apesar de os holofotes estarem voltados para a pluralidade de interpretações do art. 927, o art. 926 traz uma importante contribuição para a implementação de um sistema de valorização de precedentes ao inovar no ordenamento e prever claramente que os tribunais devem uniformizar sua jurispridência e mantê-la estável, íntegra e coerente.

Diante desse dispositivo fica evidente que, no momento da tomada de decisão jurídica, o julgador deve dialogar com as decisões anteriores sobre o assunto - dever de autorreferência - e buscar uma interpretação uniforme do direito.

O dever de uniformizar a jurisprudência pressupõe que um tribunal não seja omisso diante de decisões divergentes sobre um mesmo assunto entre seus órgãos fracionários ${ }^{73}$. A principal forma de concretizar esse dever é através da edição de súmulas ${ }^{74}$ que, por sua vez, devem ser elaboradas em fidelidade às cirunstâncias fáticas dos precedentes que ensejaram a sua criação, buscando, dessa forma, evitar o problema da edição de súmulas de forma abstrata ${ }^{75}$.

Associado ao dever de sintetizar a jurisprudência em súmulas está o dever de conferir publicidade adequada aos precedentes adotados. Por isso, o art. $927, \S 5^{\circ}$ prevê que os tribunais deverão organizar seus precedentes por tema (questão jurídica tratada) e divulgá-los de preferência, na rede

\footnotetext{
73 "Se a divergência entre tribunais já não é boa para a segurança jurídica e, por conseguinte, para o sistema de precedentes, a divergência interna é ainda pior, porque impede que se identifique a posição do tribunal". CRAMER, Ronaldo. Op. cit., p. 124.

${ }^{74}$ Ibid. p. 124.

${ }^{75}$ São exigências dos parágrafos $1^{\circ} \mathrm{e} 2^{\circ}$ do art. 926 do CPC/2015.
} 
mundial de computadores, tornando-os acessíveis aos julgadores e jurisdicionados ${ }^{76}$.

$\mathrm{O}$ art. 926 determina, ainda, o dever de manter íntegra e coerente a jurisprudência. Didier Jr., Braga e Oliveira entendem que apesar de tratarse, na realidade, de dois deveres distintos, eles formam um amálgama ${ }^{77}$, tornando difícil compreender um sem o outro. Defendem os autores que o melhor termo seria o demanter a jurisprudência consistente, entendendo que esse termo designaria o conjunto dos deveres "coerência e integridade" 78 ".

A jurisprudência pode ser coerente, mas inconsistente, na medida em que a interpretação do direito dada ao caso pode ser coerente do ponto de vista lógico, mas a argumentação que sustenta a ratio decidendi pode ser frágil e lacunosa. E, de oturo lado, a jurisprudência pode ser íntegra mas incoerente, na medida em que o tribunal pode decidir em atenção à unidade do Direito, às peculiaridades de um microssistema ou às relações entre o processo e o direito material, mas o faz a partir de distinções inconsistentes, teorias obsoletas ou sem enfrentamento de todos os argumentos suscitados em torno da controvérsia.

A coerência deve ser concretizada em duas dimensões: uma formal e outra substancial ${ }^{79}$. No aspecto formal está ligada à ideia de nãocontradição, e, no substancial, está associada à noção de conexão positiva de sentido. Além disso, seus efeitos podem ser observados também em duas dimensões: uma interna e outra externa ${ }^{80}$. Internamente, relaciona-se ao dever de fundamentação para a construção do precedente ${ }^{81}$, e externamente, a coerência é uma imposição do princípio da igualdade, na medida em que os tribunais devem coerência às suas próprias decisões anteriores e à linha evolutiva da jurisprudência ${ }^{82}$. Não pode um tribunal contrariar o seu próprio

\footnotetext{
${ }^{76}$ Ibid. p. 489.

${ }^{77}$ Ibid. p. 490.

78 Ibid. p. 491.

79 DIDIER JR., Fredie; BRAGA, Paula Sarno; OLIVEIRA, Rafael Alexandria de. Op. cit., p. $492-$ 493.

${ }^{80}$ Ibid. p. 493-495.

${ }^{81}$ Dimensão da congruência, um dever exigido de qualquer decisão judicial.

82 Nesse sentido dispõem os enunciados 454 e 455 do Fórum Permanente de Processualistas Civis. Estabelecem, respectivamente que "Uma das dimensões da coerência a que se refere o caput do
} 
entendimento, salvo quando este for superado. O dever de coerência impõe, ainda, que as distinções aptas a afastar a aplicação do precedente sejam feitas de forma coerente.

Essa dimensão externa da coerência parece estar atrelada à exigência de estabilidade da jurisprudência, na medida em que as decisões devem ser constantes e uniformes a respeito de determinada matéria e não podem simplesmente ser abandonadas ou modificadas discricionariamente ${ }^{83}$. Teresa Wambier considera a estabilidade é fundamental para conferir credibilidade ao judiciário ${ }^{84}$.

Além disso, o Novo Código prevê que os tribunais devem manter a jurisprudência íntegra. Esse ideia de integridade associa-se à ideia de unidade do Direito ${ }^{85}$, de consideração da história institucional de determinada matéria. Isso significa que "um tribunal, ao proferir decisão sobre um determinado tema, deve levar em conta toda a evolução histórica das decisões proferidas, anteriormente, sobre o mesmo tema" ${ }^{\text {" }}$.

Dito isso, os deveres de coerência, integridade e estabilidade parecem exigir um dever de autorreferência ${ }^{87}$, entendido como o dever de dialogar com os precedentes anteriores. Nesse ponto ${ }^{88}$, podemos empregar

art. 926 consiste em os tribunais não ignorarem seus próprios precedentes (dever de autorreferência)" e que "Uma das dimensões do dever de coerência significa o dever de nãocontradição, ou seja, o dever de os tribunais não decidirem casos análogos contrariamente às decisões anteriores, salvo distinção ou superação".

83 “(...) não pode um órgão jurisdicional decidir uma matéria a cujo respeito exista jurisprudência constante simplesmente ignorando essa linha decisória, promovendo uma flutuação de entendimentos que, contraria a exigência de segurança jurídica. A estabilidade da jurisprudência exige, também, que seus próprios precedentes sejam observados, inclusive por seus órgãos fracionários". CÂMARA, Alexandre Freitas. O novo processo civil brasileiro. São Paulo: Atlas, 2015. p. 427.

84 "Precedentes e evolução do direito". Direito jurisprudencial. WAMBIER, Teresa Arruda Alvim (coord.). São Paulo: Revista dos Tribunais, 2012, p. 40. Apud. CRAMER, Ronaldo. Op. cit., p. 125 .

86 CÂMARA, Alexandre Freitas. Op. cit., p. 431-432.

${ }^{87}$ Nesse sentido, o enunciado 316 do Fórum Permanente de Processualistas Civis dispõe que "a estabilidade da jurisprudência do tribunal depende também da observância de seus próprios precedentes, inclusive por seus órgãos fracionários".

88 Vários autores fazem essa referência à metáfora do romance em cadeia de Ronald Dworkin ao falar do art. 926 do CPC/2015. Entretanto, alguns mencionam a metáfora ao fazerem uma relação com o dever de coerência (como Didier Jr., Braga e Oliveira), outros mencionam atrelada à noção de integridade do ordenamento (como Ronaldo Cramer e Alexandre Câmara). A meu ver, isso parece demonstrar que há uma dificuldade na determinação is olada dos conceitos, que possuem uma inters eção de sentido e se complementam, de certa forma. Dito isso, parece que a ideia de um 
a conhecida metáfora do romance em cadeia, elaborada por Ronald

Dowkin, segundo a qual na construção do Direito, cada julgador escreve um capítulo, mas não pode deixar de dialogar com o capítulo anterior, para que a história seja coerente 8990 .

Essa linha sequencial entre as decisões parece representar um dever de coerência até mesmo para superar um precedente ou demonstrar o distinguishing. 'O respeito aos precedentes envolve o ato de segui-los, distingui-los ou revogá-los, mas jamas ignorá-los”. Nesse sentido:

A prática jurídica precisa se preocupar com o que foi feito anteriorente. (...) [a autorreferência] torna a prática mais comprometida com a coerência no discurso jurisdicional, por meio da criação de uma espécie de linha sequencial de decisões" Às vezes, nem mesmo o próprio julgador observa a sua própria cadeia decisória, submetido que está às idiossincrasias decisórias de uma multiplicidade de assessores e analistas ${ }^{91}$.

Os deveres de estabilidade e consistência (entendido este como a junção dos deveres de integridade e coerência), devem ser observados na eficácia vertical e horizontal dos precedentes. Se os tribunais pudessem negar livremente suas próprias decisões ou as decisões das Cortes Superiores, não seria viável pensar na existência de um Direito uniforme.

Para auxiliar nesse objetivo de uniformização da jurisprudência, o instituto dos embargos de divergência permite que sejam resolvidos eventuais dissensos dentro de um mesmo tribunal, e, após julgados os embargos, as turmas/câmaras ficam vinculadas àquele entendimento, salvo se presentes os pressupostos para a revogação do precedente ${ }^{92}$.

\footnotetext{
romance em cadeia estaria intrinsecamente relacionada aos deveres de coerência, integridade e estabilidade. Para ver a posição de cada um dos autores, ver DIDIER JR., Fredie, BRAGA, Paula Sarno, OLIVEIRA, Rafael Alexandria de. Op. cit., p. 293-294; CRAMER, Ronaldo. Op. cit., p. 127-128; CÂMARA, Alexandre Freitas. Op. cit., p. 431-432.

${ }^{89}$ DIDIER JR., Fredie; BRAGA, Paula Sarno; OLIVEIRA, Rafael Alexandria de. Op. cit., p. 493494.

90 "Cada juiz ou tribunal, ao proferir uma decisão, deve levar em conta as decisões anteriormente proferidas acerca daquela mesma matéria, de modo a tratá-las como se fossem os capítulos anteriores de um romance em cadeia. E a decisão que agora será proferida é o novo capítulo, que precisa formar com as anteriores um todo íntegro, respeitando-se, deste modo, a história institucional das decisões a respeito daquela matéria. Só assim se poderá considerar íntegra a jurisprudência dos tribunais". CÂMARA, Alexandre Freitas. Op. cit., p. 432.

${ }^{91}$ MACÊDO, Lucas Buril de. Precedentes judiciais e o direito processual civil, cit., p. 271. Apud. DIDIER JR., Friedie; BRAGA, Paula Sarno; OLIVEIRA, Rafael Alexandria de. Op. cit., p. 494.

${ }^{92}$ MARINONI, Luiz Guilherme. Op. Cit., p. 94-95.
} 
Nesse sentido, o próprio STJ já ressaltou a importância de um tribunal seguir suas próprias decisões. Veja-se:

O Superior Tribunal de Justiça foi concebido para um escopo especial: orientar a aplicação da lei federal e unificar-lhe a interpretação, em todo o Brasil. Se assim ocorre, é necessário que sua jurisprudência seja observada, para se manter firme e coerente. (...) Se deixarmos que nossa jurisprudência varie ao sabor das convicções pessoais, estaremos prestando um desserviço a nossas instituições. Se nós - integrantes da Corte - não observamos as decisões que ajudamos a formar, estaremos dando um sinal para que os demais órgãos judiciários façam o mesmo. Estou certo de que, em acontecendo isso, perde sentido a existência de nossa Corte. Melhor será extinguí- $\mathrm{l}^{93}$.

Objetivamos até aqui explicitar como os precedentes vem sendo tratados pelos dispositivos do CPC/2015. No próximo capítulo destrincharemos alguns conceitos importantes para entender melhor o que é um precedente e quais são os elementos que o constituem.

93 STJ, Corte Especial, AgRg nos Embargos de Divergência no REsp 228432, rel. Min. Humberto Gomes de Barros, DJ 18.03.2002. Apud. MARINONI, Luiz Guilherme. Op. Cit., p. 95. 


\section{Determinação da norma emergente do precedente}

\subsection{Conceito de precedente}

O conceito de precedente pode ser definido em dois sentidos: próprio ou impróprio ${ }^{94}$. Em sentido próprio se refere à decisão judicial do caso que que fixou a norma jurídica que exercerá influência - seja persuasiva ou vinculante - nas decisões de casos futuros.

Em sentido impróprio, o precedente significa a norma jurídica extraída do caso concreto que servirá de parâmetro decisório para os casos futuros. Trata-se, na verdade, da ratio decidendi, e sua identificação depende da análise dos fatos relevante do caso concreto, da questão posta em juízo, da fundamentação e do que restou decidido.

No Common Law, via de regra, um julgado não nasce com o status de precedente, sendo reconhecido como tal em decisões posteriores. Dito isso, defendem alguns que não seria possível falar em sistema de precedentes no Brasil, uma vez os precedentes que já nasceriam com esse status 95 .

Se considerarmos que não nascer com o status de precedente é, de fato, um elemento essencial para a definição do conceito, existiriam poucos os precedentes no sistema brasileiro. Entretanto, Ronaldo Cramer defende que o reconhecimento posterior não é elemento essencial para a definição de precedente. "Se o precedente já nasce como tal ou se é identificado assim posteriormente, isso diz respeito ao momento de reconhecimento do precedente, não sendo determinante para a sua definição"

\footnotetext{
94 CRAMER, Ronaldo. Precedentes judiciais: teoria e dinâmica. Rio de Janeiro: Forense. 2016. p. 77-78.

95 Em crítica recente, Lenio Streck afirma esse posicionamento: "precedentes do common law não admitem, nem de longe, isso que querem estabelecer aqui no Brasil. Por uma razão simples: precedentes do common law não-são-feitos-para-resolver-casos-futuros; precedentes não nascem precedentes; sua aplicação posterior é contingencial. Simples assim”. STRECK, Lênio Luiz; ABBOUD, Georges. O solilóquio epistêmico do ministro Roberto Barroso sobre precedentes. Disponível em: http://www.conjur.com.br/2016-nov-03/senso-incomum-soliloquio-epistemicominis tro-barroso-precedentes. Acessado em: 09/11/2016.

96 Sobre esse ponto, Ronaldo Cramer adverte que há o risco de, sabendo que sua decisão será vinculante, o magistrado ir além dos limites legais e "legislaer". Entretanto, informa o autor que
} 
Nesse sentido, cabe importante consideração que é feita mesmo no Common Law. Autores como Neil Duxbury enfatizam a necessidade de, no momento de decidir, o julgador considerar que sua decisão pode constituir um precedente:

The point that precedents have a consequential as well as an historical dimension, while a good one, can be overemphasized. Since 'the conscientious decisionmaker must recognize that future conscientious decisionmakers will treat her decision as precedent', Schauer argues, 'today's conscientious decisionmakers are obliged to decide not only today's case, but tomorrow's as well ${ }^{97}$.

Marinoni sustenta que seria possível pensar que toda decisão judicial é um precedente, entretanto, ambos não se confundem. Uma decisão pode não ter os caracteres necessários para configurar um precedente, seja porque já houve decisão anterior sobre a questão, por se limitar a reproduzir a lei, por não apresentar argumentos endossados pela maioria do colegiado, seja porque não analisou todos os principais argumentos relacionados à questão de direito posta a julgamento. Além disso, o autor ressalta que podem ser necessárias inúmeras decisões para que um precedente seja definitivamente delineado ${ }^{98}$.

\subsection{Precedente, jurisprudência e súmula}

Quando o precedente é reiteradamente aplicado, passando a refletir o posicionamento predominante do tribunal, dizemos que este se torna jurisprudência. Note-se que a jurisprudência não é a existência de um ou de

\footnotetext{
esse ativismo pode ser combatido, pois a parte interessada pode interpor os recursos cabíveis para combater excessos na formação e no uso de qualquer precedente. É preferível combater os exageros do ativismo que deixar de considerar precedente um julgado que já nasce como tal. CRAMER, Ronaldo. Op. cit., p. 79-80.

97 "O ponto é que os precedentes têm uma consequente e uma histórica dimensão, enquanto que uma boa pode ser subestimada. Desde 'o tomador de decisão consciente deve reconhecer que os futuros tomadores de decisão irão tratar sua decisão como precedente', Schauer argumenta, 'tomadores de decisão de hoje são obrigados a decidir não apenas o caso de hoje, mas os de amanhã de também"” (Tradução livre - DUXBURY, Neil. The nature and authority of precedent. Cambridge: Cambridge Press, 2008, p. 4). Apud. CRAMER, Ronaldo. Op. cit., p. 80.

${ }^{98}$ MARINONI, Luiz Guilherme. Op. cit., p. 156-157.
} 
alguns julgados em determinado sentido, mas a reiteração atual e prevalecente no âmbito de determinado tribunal ${ }^{99}$.

As súmulas, por sua vez, não foram concebidas para servir como precedente, mas para organizar o trabalho dos ministros, identificando como a questão foi julgada e evitando julgamentos contraditórios sobre o mesmo assunto. Somente com o tempo, sobretudo a partir do impacto de seu uso na praxe forense, a súmula tornou-se um importante e persuasivo precedente do nosso sistema jurídico ${ }^{100}$.

Como vimos, a ratio decidendi, constitui o núcleo do precedente, que, quando reiteradamente aplicado, se transforma em jurisprudência, que pode dar origem a uma súmula. A súmula é o enunciado normativo (texto) da ratio decidendi de uma jurisprudência dominante (precedente reiterado). Dessa forma, pode-se dizer que há uma evolução entre os conceitos: precedente, jurisprudência e súmula. São noções distintas, porém, umbilicalmente ligadas ${ }^{101}$.

Como todo texto, o enunciado da súmula será objeto de interpretação, razão pela qual deve ser redigida em termos precisos e claros de modo a não se afastar da ratio decidendi extraída da jurisprudência ${ }^{102}$. Mas será que a súmula deve ser considerada precedente?

Apesar de, a rigor, a súmula não ser precedente, Ronaldo Cramer entende a súmula deve ser considerada precedente lato sensu, pois é um provimento judicial que representa o precedente que a originou.

Considerar a súmula como precedente lato sensu não significa que deva ser usada como texto autônomo ou como resumo da norma do precedente, mas deve ser interpretada à luz do precedente, bem como das

99 REDONDO, Bruno Garcia. Precedente Judicial no Direito Processual Civil Brasileiro. In: MENDES, Aluísio Golçaves de Castro; MARINONI, Luiz Guilherme; WAMBIER, Teresa Arruda Alvim (coord.). Direito juris prudencial: volume 2. São Paulo: RT, 2014. p. 11-12.

100 CRAMER, RONALDO. Op. cit., p. 46.

${ }^{101}$ DIDIER JR., Fredie, BRAGA, Paula Sarno; OLIVEIRA, Rafael Alexandria de. Op. cit., p. 500.

102 REDONDO, Bruno Garcia. Op. cit., p. 12. 
decisões que a aplicaram. Entretanto, sabe-se que não é assim que comumente são aplicadas na prática brasileira.

\subsection{Requisitos para a formação de um precedente no Direito Brasileiro}

A doutrina não é unânime quanto aos requisitos para definição do conceito de precedente.

Ronaldo Cramer ${ }^{103}$ entende que, para ser considerada precedente, a decisão deve ser de um tribunal, não podendo ser decisão do relator, uma vez que o princípio da colegialidade determina que os tribunais fazem-se representar por seu colegiado, não por decisões unipessoais. Além disso, essa decisão precisa ser estável, ou seja, não pode estar pendente de recurso. Dito isso, o autor entende que a decisão de primeiro grau não pode ser considerada precedente, uma vez que a nossa tradição processual apenas considera como jurisprudência o posicionamento dos tribunais.

Ou seja, para que seja um precedente, o autor defende é preciso que o julgado: (i) seja proferido por um tribunal; (ii) tenha criado, a partir da interpretação da lei, uma nova norma jurídica; e (iii) seja estável (não pendente de recurso).

Entretanto, Luiz Guilherme Marinoni sustenta que apenas as decisões das Cortes Supremas estariam voltadas a formar precedentes. O autor entende que os juízes e tribunais de apelação possuem a função de resolver conflitos (resolution of disputes) e as Cortes Supremas possuem a função de desenvolvimento do Direito ou enriquecimento das normas jurídicas (enrichment of the supply of legal rules) ${ }^{104}$. Nesse entendimento, os tribunais de apelação não firmariam precedentes, uma vez que não possuem a função de atribuir sentido ao direito, mas apenas de resolver

103 CRAMER, Ronaldo. Op. cit., p. 87-88.

${ }^{104}$ MARINONI, Luiz Guilherme. Op. cit., p. 290-291. 
litígios, devendo focar sua atenção nos fatos litigiosos e nas provas de modo a revisar a "justiça" da sentença ${ }^{105}$.

Isso não quer dizer que os juízes e tribunais não devam dedicar seu tempo e esforço para dar interpretação aos textos legais, pois possuem a importante função de colaborar para o amadurecimento da interpretação das leis e da solução das questões de direito ${ }^{106}$. Ou seja, como os juízes e tribunais não podem negar o sentido de direito atribuído pelas Cortes Supremas, devem dar início à função interpretativa do Judiciário, sedimentando seu entendimento sobre o direito, e permitindo que as Cortes Supremas possam resolver os impasses interpretativos a partir de interpretações delineadas - e não com base em decisões dispersas e incapazes de revelar o pensamento do tribunal ${ }^{107}$.

Considerando as observações dos referidos autores, parece que ambos voltaram-se especialmente para a eficácia vertical dos precedentes. Se adotarmos a definição precedente como "a decisão judicial tomada à luz de um caso concreto que pode servir como diretriz para o julgamento posterior de casos análogos ${ }^{108}$ ", parece que a primeira decisão de um juiz de primeiro grau sobre determinado assunto seria um auto-precedente enquanto não houver pronunciamento dos tribunais superiores sobre aquele tema. Sabemos que esses auto-precedentes, por óbvio, não vinculam outros julgadores, muito menos instâncias superiores e também não impõem ao juiz o mesmo ônus que impõe um precedente de um tribunal. Juízes podem deixar de adotar seus auto-precedentes caso os considerem equivocados, mas, para tal, devem exercer o dever de argumentação. Dessa forma, autoprecedentes representam uma forma de controle das decisões judiciais, na

\footnotetext{
105 “Um tribunal de apelação não firma precedentes por uma razão muito simples. Não é função sua atribir sentido ao direito e dar-lhe desenvolvimento, mas resolver litígios. Os tribunais atual de modo a revisar a "justiça" das sentenças de primeiro grau sem qualquer restrição. Há, assim, dois juízos repetitivos sobre o litígio, devendo o tribunal estar atento aos fatos litigiosos e à prova". Ibid. p. 291.

106 Ibid. p. 291.

107 “A jurisprudência uniforme do tribunal é formada a partir do resultado dos recursos, que devem espelhar uma determinada solução interpretativa, expressa na fundamentação e na ementa do acórdão”. Ibid. p. 291.

108 DIDIER JR., Fredie; BRAGA, Paula Sarno; OLIVEIRA, Rafael Alexandria de. Op. cit., p. 453.
} 
medida em que um magistrado deve ser coerente e decidir dialogando com suas decisões anteriores sobre o tema.

\subsection{Elementos do precedente: ratio decidendi e obiter dictum}

Ao decidir um caso, o magistrado cria duas normas jurídicas ${ }^{109}$ 110: (i) uma individual, que será lançada no dispositivo da decisão e que objetiva resolver a questão posta em juízo (conclusão sobre a procedência ou improcedência da demanda e tem aptidão para ficar acobertada pela eficácia da coisa julgada); (ii) e uma de caráter geral, fruto da compreensão dos fatos envolvidos na causa e que poderá ser aplicada a situações concretas que se assemelhem à que lhe deu origem.

Por isso, quando falamos em precedentes vinculantes ou persuasivos, nos referimos, na verdade, à ratio decidendi (também chamada de holding ${ }^{111}$ ), que é um dos elementos do precedente.

Apesar de contida na fundamentação, a ratio decidendi com ela não se confunde. A fundamentação não vincula diretamente casos futuros, mas é a partir de sua análise que será possível identificar a norma do precedente (ratio). Entretanto, há algumas partes que podem ser excluídas da interferência em casos futuros.

Constitui obiter dictum qualquer manifestação não necessária à solução do caso concreto, a exemplo de considerações marginais trazidas pela corte; argumentos de um dos membros do colegiado que não foram acolhidos pelos demais; ou dissensos constantes nos votos divergentes ${ }^{112}$. São argumentos e considerações expostos apenas de passagem na motivação da decisão que constituem opinião jurídica adicional, paralela e

\footnotetext{
109 Ibid. p. 455-457.

${ }^{110}$ REDONDO, Bruno Garcia. Op. cit., p. 7.

111 Apesar de alguns pontuarem uma diferença entre holging e ratio decidendi, a maioria dos autores utilizam as expressões como sinônimas, informando que o termo ratio decidendi é mais comumente utilizado na Inglaterra, enquanto holding é mais frequente entre os norte-americanos. Nesse sentido: MELLO, Patrícia Perrone Campos. Precedentes. Rio de Janeiro: Renovar. 2008, p. 118; DIDIER JR., Fredie; BRAGA, Paula Sarno; OLIVEIRA, Rafael Alexandria de. Curso de direito processual civil, v. 2. 10 ed. Salvador: Juspodivm, 2015, p. 455.

112 MELLO, Patrícia Perrone Campos. Op. cit., p. 125.
} 
dispensável para a fundamentação e conclusão da decisão. Normalmente é definido de forma negativa: é obiter dictum a proposição ou regra jurídica que não compuser a ratio decidendi.

Entretanto, apesar de não servir como precedente, o obiter dictum não é desprezível, podendo servir de aspecto argumentativo ou sinalizar uma futura orientação do tribunal, por exemplo. Tribunais podem conferirlhe algum peso impositivo quando houver evidência de que resultou de um exame especialmente atento da Corte, ainda que não fosse necessário à decisão ${ }^{113}$.

É importante identificar o que é ratio e o que é dictum, no precedente, entretanto, nem sempre é tarefa fácil. Nas palavras de Ronaldo Cramer:

A diferenciação entre ratio decidendi e obiter dictum consiste numa das questões mais difíceis do Common Law, havendo um número razoável de correntes para determinar esses dois elementos do precedente.

(...)

E essa dificuldade normalmente decorre do fato de que ratio decidendi e obiter dictum normalmente se misturam, já que se encontram na mesma parte do julgado e não estão discriminados formalmente um do outro. Não raras vezes, um julgado, na mesma frase, expõe um dos motivos da decisão (ratio decidendi) e faz uma digressão sobre esse motivo (obiter dictum $)^{114}$.

A formulação ratio suscita a análise de várias questões, entre elas: quais são as formulações jurídicas efetivamente imprescindíveis à decisão e como podem ser identificadas; quais são os métodos para sua identificação; com que grau de generalidade se deve formular o comando extraído de um caso concreto ou com que amplitude se devem tratar os fatos que o geraram $^{115}$.

Abordaremos, no próximo tópico, alguns métodos utilizados para a identificação da ratio decidendi.

\footnotetext{
113 Ibid. p. 126.

114 CRAMER, Ronaldo. Op. cit., p. 104.

115 MELLO, Patrícia Perrone Campos.Op. cit., p. 120.
} 


\subsection{Como identificar a ratio decidendi?}

Existem diversos métodos para identificação da ratio. Luís Roberto Barroso e Patrícia Perrone entendem que podemos agrupar as discussões travadas no Common Law em duas categorias: a) método fático-concreto; e b) método abstrato-normativo ${ }^{116}$.

$\mathrm{O}$ método fático-concreto entende que a ratio decidendi corresponderia à regra extraída de um conjunto de fatos. Em qualquer situação que estejam presentes os fatos A e B (relevantes), e presente ou não o fato $\mathrm{C}$ (irrelevante), o resultado deverá ser X. Nesse método, o mais relevante é o que o tribunal decidiu quanto aos fatos, não importando os fundamentos que invocou para justificar a decisão. A utilização desse método tende à criação de holdings mais restritivas, presas às particularidades do caso. Além disso, devemos ressaltar que a compreensão sobre quais seriam os fatos relevantes de um caso para definir o comando emergente da situação pressupõe considerar o que a Corte disse e compreender minimamente as razões que levaram a tal avaliação ${ }^{117}$.

O método abstrato-normativo determina que a lide seja solucionada de uma forma mais ampla. Ao decidir um caso concreto, os tribunais não solucionam apenas a lide posta a julgamento, mas também decidem como serão julgados os casos semelhantes futuros. Ou seja, enunciam explícita ou implicitamente a regra capaz de solucionar não apenas a demanda em exame, como também os casos a ela semelhantes. Dessa forma, os fundamentos justificantes, as razões oferecidas pelo tribunal, seriam fundamentais para a enunciação da regra vinculante e para a determinação de sua racionalidade.

Como mencionamos, filiar-se ao método fático-concreto geralmente ocasiona uma compreensão mais restritiva dos efeitos normativos. Levado às últimas consequências, poderia significar que pouquíssimos casos seriam

\footnotetext{
116 BARROSO, Luís Roberto; MELLO, Patrícia Perrone Campos. Trabalhando com uma nova lógica: a ascensão dos precedentes no direito brasileiro. Disponível em: http://s.conjur.com.br/dl/artigo-trabalhando-logica-ascensao.pdf. Acessado em 10/11/2016; MELLO, Patrícia Perrone Campos. Op. cit., p. 127.

117 BARROSO, Luís Roberto; MELLO, Patrícia Perrone. Op. cit., p. 20.
} 
controlados por decisões anteriores, uma vez que toda demanda possui alguma peculiaridade. Esse extremo acabaria por permitir que situações essencialmente iguais recebessem tratamento desigual em virtude de distinções arbitrárias, indo contra o objetivo de um sistema de precedentes.

Além disso, os fatos importantes para o deslinde de uma causa não se identificam sozinhos, razão pela qual será necessário que existam critérios para determinar quais seriam os fatos juridicamente relevantes e em que nível de similitude e generalidade devem ser enunciados. Dessa forma, o que foi decidido pela Corte em sua fundamentação se mostra absolutamente essencial mesmo para aqueles que defendem a adoção do método fáticoconcreto $^{118}$.

Entre esses métodos, o importante não é adotar um ou outro, mas identificar o que há de eloquente em cada um para a identificação dos contornos da ratio. Um deles explicita a relevância da realidade fática para para a determinação do precedente e o outro afirma a importância dos fundamentos deduzidos pela corte para tal fim ${ }^{119}$.

Dito isso, passaremos à análise de alguns dos métodos mais comuns para a identificação da ratio no Common Law. Apesar de parecer-nos que esses métodos já estão, de alguma forma, agrupados nas categorias expostas acima, optamos por estudá-los mais detalhadamente para reforçar a conclusão exposta acima no que se refere à isuficiência de se adotar um único método específico.

Como primeiro método, citaremos aquele desenvolvido por Eugene Wambaugh $^{120}$, conhecido como teste de Wanbaugh ${ }^{121}$. Segundo esse método, a ratio decidendi seria a questão essencial sem a qual o julgamento importaria em conclusão diferente. O teste funciona da seguinte forma: primeiramente, deve ser formulada a suposta proposição de direito e, após,

\footnotetext{
118 MELLO, Patrícia Perrone ampos. Op. cit., p. 128-130.

119 Ibid. p. 130.

120 Buscando conciliar conceitos, acredito que tal método já esteja inserido no grupo que ad ota o método abstrato-normativo, na clas sificação de Barroso e Mello exposta acima.

121 MARINONI, Luiz Guilherme. Op. cit., p. 162; DIDIER JR., Fredie; BRAGA, Paula Sarno; OLIVEIRA, Rafael Alexandria de. Op. cit., p. 462; CRAMER, Ronaldo. Op. cit., p. 109-110.
} 
deve-se inserir uma palavra que inverta seu significado. Se disso decorrer mudança na conclusão final do julgamento, a proposição é ratio decidendi. De outro lado, se a nova proposição resultar em igual decisão, a proposição original representa consideração marginal, prescindível para a conclusão, sendo, portanto, obiter dictum.

Essa técnica vem sendo criticada pela doutrina contemporânea do Common Law. Existem demandas que suscitam mais de uma questão de direito ou mais de uma razão de decidir, tornando mais complexa a definição da regra utilizada pelo tribunal. Se as justificativas forem cumulativas, gerarão uma única norma vinculante, e, quando houver a inversão de uma delas, a outra será suficiente para manter a decisão, não permitindo que a primeira seja identificada como ratio decidendi. Dessa forma, o teste de Wanbaugh não é eficaz quando a decisão se baseia em dois fundamentos que, por si só, conduzem à solução igual.

Surge, então, o método de Goodhart ${ }^{122}$, que dá maior ênfase aos fatos e propõe que a ratio decidendi seja determinada mediante a identificação dos fatos tratados como fundamentais ou materiais no precedente, assim como por meio da análise da decisão neles embasada ${ }^{123}$. Nesse caso, a ratio decidendi, ou principle of a case, nas palavras do autor, não se encontra nas razões ou opinião do julgador, mas na análise dos fatos destacados como importantes na causa e na decisão que neles se funda. Esse método prestigia que casos iguais sejam tratados de mesma forma e, para que não seja aplicado o precedente, o caso deve possuir outros fatos considerados materiais ou os fatos considerados materiais no caso precedente devem estar ausentes no caso sob julgamento.

Rupert Cross propõe um método eclético ${ }^{124}$ (considerando as duas propostas anteriores: de Wambaugh e Goodhart) e dispõe que "a ratio

\footnotetext{
122 MARINONI, Luiz Guilherme. Op. cit., p. 162; DIDIER JR., Fredie; BRAGA, Paula Sarno; OLIVEIRA, Rafael Alexandria de. Op. cit., p. 462; CRAMER, Ronaldo. Op. cit., p. 110-111.

123 Acredito que, na classificação de Barroso e Mello, o método de Goodhart esteja inserido no grupo fático-concreto.

124 Didier, Braga e Oliveira entendem que o melhor método seria aquele proposto por Rupert Cross, sendo, poranto, um método eclético, que considera as propostas de Wambaugh e de
} 
decidendi de um caso é qualquer regra de direito expressa ou implicitamente tratada pelo juiz como passo necessário para alcançar a sua conclusão $^{125 "}$.

Neil MacCormick faz uma crítica à definião de Cross, imputando-a como muito abrangente. MacCormick pontua que qualquer caso em que uma lei estivesse sendo aplicada ou interpretada, ela corresponderia a uma regra sem a qual a conclusão não poderia ser alcançada, entretanto, ninguém supõe que uma lei possa ser a ratio. Por isso, seria preferível definir a ratio como solução do juiz ao invés de como uma regra da qual sua conclusão dependa. O autor adverte, ainda, que o termo "necessidade" compreenderia muitos significados, por isso, propôs uma subsituição pelo termo "suficiente" 126.

A questão parece girar em torno do significado dos vocábulos "necessário" e "suficiente". Se o passo é necessário, ele é imprescindível, obrigatório. Se ele é suficiente, significa que ele é apto, é o bastante para se chegar ao resultado.

Entretanto, a discussão a respeito do significado de ratio decidendi e obiter dictum ocorre porque o significado de um está atrelado ao outro e em diversas situações torna-se bastante difícil essa distinção. Há questões que nada se relacionam com o julgado e são mencionadas "de passagem", e há outras questões que, embora não precisassem ser apreciadas para se chegar à decisão, possuem íntima relação com o caso e podem ter sido enfrentadas de forma aprofundada pela Corte ou até mesmo terem sido acolhidas unanimamente pelos julgadores ${ }^{127}$.

Rupert Cross divide questões em dependentes e independentes para justificar a qualificação de uma questão como obiter dictum. Quando existem duas questões, mas apenas uma delas é suficiente para dar ganho de causa à parte e quando a abordagem dela não depende da abordagem da

Goodhart. DIDIER JR., Fredie; BRAGA, Paula Sarno; OLIVEIRA, Rafael Alexandria de. Op. cit., p. 462.

${ }^{125}$ MARINONI, Luiz Guilherme. Op. cit., p. 166.

${ }^{126}$ MARONINO, Luiz Guilherme. Op. cit., p. 166-167.

127 Ibid. p. 169. 
primeira, seria uma questão independente. De outro lado, quando a segunda questão apenas pode ser apreciada se acolhida a primeira, trata-se de questão dependente.

No caso Perry v. Kendrick's Transport ${ }^{128}$ havia duas questões perante a Corte de Apelação: uma referente à impossibilidade de se obter indenização por injúrias pessoais com base em Rylands v. Fletcher e a outra relativa à possibilidade de o réu alegar no recurso que o dano havia sido causado por terceiro. A Corte decidiu pela possibilidade de se obter indenização por injúrias pessoais (a favor do autor-apelado), entretanto, julgou a favor do réu-apelante, entendendo que o dano havia sido causado por fato de um terceiro.

Havia questões independentes no caso, pois uma foi decidida em favor do apelado e outra em favor do apelante. Cross afirma que a decisão a respeito da primeira questão (possibilidade de se obter indenização por injúrias pessoais) seria tecnicamente obiter dictum, sendo ratio decidendi apenas a segunda questão. Wambaugh, de mesma maneira, entenderia que a primeira questão seria dictum, uma vez que ainda que invertido o seu sentido, o resultado do julgamento seria o mesmo. Goodhart também concluiria no mesmo sentido que os dois anteriores, uma vez que a Corte teria considerado como imaterial o fato de que injúrias sofridas pelo autores eram pessoais e teria concluído que era cabível a defesa de que os danos haviam sido causados por terceiros ${ }^{129}$.

Apesar de tecnicamente ter sido considerado dictum perante à Câmara dos Lordes, Cross sustenta que é difícil acreditar que um órgão de primeiro grau se sentiria livre para decidir que os danos por injúrias pessoais não podem ser cobrados com base em Rylands v. Fletcher. O obiter dictum do caso referido tratava de forma aprofundada um ponto de direito relacionado ao caso, e, por isso, teria intensidade tão forte quanto a do efeito obrigatório particular à ratio decidendil30, devendo ser

\footnotetext{
128 Ibid. p. 169.

${ }^{129}$ Ibid. p. 170.

${ }^{130}$ Ibid. p. 170.
} 
diferenciado de outros obiter dicta que representem excesso de argumentação ou tratem de pontos irrelevantes.

Essas considerações demonstram, mesmo no Common Law, a insuficiência de se adotar um método ou outro para identificar a ratio decidendi. Marinoni reputa essa problemática ao fato de que, no Common Law, a noção de ratio decidendi estaria atrelada à solução da causa e por isso não é de se estranhar que não estejam ligadas a argumentos favoráveis à parte vencida ou que, ainda que favoráveis ao vencedor, não fossem necessárias para se chegar à conclusão do caso.

No sistema brasileiro, em que a força dos precedentes nada deve à resolução dos casos, torna-se natural conferir autoridade de ratio decidendi às razões suficientes à solução de questões que não se ligam necessariamente à solução que é dada ao caso. Assim, por exemplo, em uma ação rescisória julgada procedente, nada impede que as razões que serviram para rejeitar uma das causas de pedir assuma a qualidade de ratio decidendi. Ora, o mesmo motivo que estimula à obrigatoriedade das decisões que resolveram os casos está presente quando se está diante de decisões que, embora sem solucionar os casos, emprestam sinigicado a questões discutidas no judiciário ${ }^{131}$.

Por isso, Ronaldo Cramer defende que, ao adotarmos um sistema de valorização de precedentes, devemos rechaçar qualquer método específico para delimitação da ratio ${ }^{132}$. Não devemos aprisionar o processo interpretativo da ratio a um tipo de método específico, uma vez que não existe apenas um método para deduzir a norma de um texto.

$\mathrm{O}$ autor sustenta, ainda, que a ratio deve ser coerente com a questão submetida à apreciação do tribunal e deve ser considerada a partir da prática decisória daquele tribunal, de forma a preservar a integridade da jurisprudência - o que é diferente de estabelecer que a ratio deve representar as razões necessárias ou suficientes para a decisão. Além disso, o pontua que a ratio não é delimitada no momento de formação do precedente, e que, por mais que possa haver essa tentativa, a ratio será

\footnotetext{
${ }^{131}$ MARINONI, Luiz Guilherme. Op. cit., p. 177.

132 "Ao trazer essas noções para o Civil law, sobretudo para o Direito brasileiro, com mais razão, deve-se rechaçar qualquer método para descobrir a ratio decidendi”. CRAMER, Ronaldo. Op. cit., p. 112.
} 
delimitada posteriormente, no momento em que for aplicada a um novo caso concreto ${ }^{133}$.

\subsection{Grau de generalidade da Ratio}

Para que um julgador possa aplicar o precedente de algum tribunal, antes precisa interpretar a decisão judicial que deu origem ao precedente e identificar a norma geral que se aplica ao caso sob julgamento. O problema é que as decisões judiciais costumam ser longas, técnicas e complexas e não anunciam essas normas jurídicas tal como o fazem as leis (através de artigos, incisos e parágrafos bem definidos) ${ }^{134}$. Nesses casos, caberá ao intérprete encontrá-la de algum modo.

Como mencionamos no tópico anterior, há diversas formas de identificar a ratio. Struchiner e Shecaira propõem uma opinião comum e plausível, que chamam de procedimento comum ${ }^{135}$. De acordo com esse procedimento, a ratio seria norma geral que, juntamente com os fatos, levaria necessariamente à conclusão do caso. Representando a argumentação do tribunal através de um silogismo jurídico, a ratio seria a norma geral que, colocada no lugar da premissa maior, levaria à justificação interna do julgado.

Interpretar e aplicar precedentes não são tarefas simples e mecânicas. Para extrair a ratio de uma decisão, deve-se reconstruir o silogismo que cumpre papel central na argumentação. Suponhamos que um intérprete, ao analisar a decisão do precedente, indentifique os fatos relevantes e a conclusão do julgado, mas não identifique claramente premissa maior

\footnotetext{
133 "Em primeiro lugar, a ratio decidendi deve ser coerente com as questões submetidas ao julgamento do tribunal. Repare-se que isso é diferente de a ratio considerar as razões necessárias e suficientes para o julgamento do caso, pporque, às vezes, algumas dessas razões, por descuido ou qualquer outro motivo, não ecorrem das questões deduzidas para julgamento.

Além disso, a ratio decidendi deve ser considerada a partir da prática decisória do tribunal, a fim de preservar a integridade da jurisprudência, conforme reclama o art. 926 do NCPC. (...) para que haja integridade, faz-se necessário que a ratio decidendi seja retirada do precedente à luz dos precedentes passados e atuais do mesmo tribunal". CRAMER, Ronaldo. Op. cit., p. 112.

134 STRUCHINER, Noel; SHECAIRA, Fábio Perin. Teoria da argumentação jurídica. Rio de Janeiro: Contraponto. 2016., p. 125.

135 Ibid. p. 125.
} 
adotada ela Corte. Diante disso, podemos perceber que, a depender do nível de generalidade, várias normas podem ser formuladas para cumprir essa função.

Para ilustrar tal possibilidade, os autores trazem o caso Riggs $v$. Palmer, em que o herdeiro envenenou seu avô, ocasionando sua morte ${ }^{136}$. A premissa maior utilizada pelo caso foi: "ninguém tem permissão para adquirir propriedade a partir do próprio crime". Entretanto, poderiam ter sido formuladas outras normas como "ninguém ter permissão para adquirir propriedade a partir de crime doloso", ou "ninguém ter permissão para lucrar a partir da própria fraude" ou "ninguém ter permissão para tirar vantagem do próprio ato ilícito".

Nessa linha, uma decisão poder ser anunciada em diferentes níveis de generalidade, não havendo uma única forma de definir o teor normativo de um julgado. Quanto mais ampla for a sua formulação, maior será seu âmbito normativo, e, consequentemente, maior será a liberdade dos julgadores no momento de decidir um caso semelhante. De outro lado, quanto mais restrita a formulação, menor será sua esfera de aplicação ${ }^{137}$.

Struchiner e Shecaira informam que o procedimento comum recomenda que seja eleita como ratio a norma mais estreita, de forma a minimizar as chances de os julgados posteriores extrapolarem a intenção do tribunal que criou o precedente.

No exemplo anterior, poderiam ser elaboradas normas ainda mais específicas, que se aproximam ainda mais das peculiaridades do caso concreto, como, por exemplo: "ninguém ter permissão para adquirir herança a partir de homicídio contra o testador, sendo este seu parente" ou ainda "ninguém tem permissão para adquirir a herança a partir de homicídio contra o testador, sendo este seu avô". Entretanto, os referidos autores sustentam que não é comum e nem desejável que julgadores optem por normas tão estreitas. A partir de determinado ponto, a especificidade da

136 Ibid. p. 125-127.

${ }^{137}$ MELLO, Patrícia Perrone Campos. Op. cit., p. 130-131. 
ratio passa a ser excessiva e iconsistente com as intenções do tribunal que criou o precedente. Mas, de uma forma geral, os autores consideram que pecar pelo excesso é mais perigoso do que pecar pela especificidade exacerbada, o que não significa que este último pecado também não deva ser evitado ${ }^{138}$.

A elaboração de critérios para a determinação da amplitude da regra é essencial para trabalhar com precedentes, especialmente se levarmos em consideração o fato de que são os julgados posteriores que primeiramente interpretarão um precedente quando se virem diante de um caso semelhante. Por isso, esses critérios para delimitar o grau de generalidade da ratio contribuem para minimizar as chances de manipulação da norma do precedente a fim de favorecer interesses mais amplos ou mais restritos.

Ressalta-se, ainda, que a determinação da generalidade da ratio produz impactos também na identificação do grupo de fatos que serão abrangidos por ela. Sabe-se que dois casos nunca são absolutamente iguais ${ }^{139}$, razão pela qual é imprescindível analisar se existe tamanha similaridade entre os casos a ponto de demandar a aplicação da norma do precedente.

O agrupamento de fatos a serem abrangidos pela norma do precedente requer que se leve em conta diversos aspectos, tais como: a semelhança entre eles, o contexto social, os argumentos articulados na Corte para a fundamentação, a linguagem adotada na decisão, os princípios de direito que a embasaram, a finalidade que se visa alcançar com a regra, eventuais distinções já afirmadas no plano normativo e como as decisões

\footnotetext{
${ }^{138}$ STRUCHINER, Noel; SHECAIRA, Fábio Perin. Op. cit., p. 128.

139 No two events are exactly alike. For a decision to be precedent for another decision does not require that the facts of the earlier and the later cases be absolutely identical. Were thar required, nothing would be a precedent for anything elese. We must therefore leave the realm of absolute identity. Once we do so, however, it is clear that the relevance of an earlier precedent depends upon how we characterize the facts arising in the earlier case. It is a commonplace that these characterizations are inevitably theory-laden. In order to asses what is a precedent for what, we must engage in some determination of the relevant similarities between the two events. In turn, we must extract this determination from some other organizing standard specifying wich similarities are important and wich we can safely ignore. SCHAUER, Frederick. Precedent. Stanford Law Review, Palo Alto, v. 39, Feb. 1987, p. 577.
} 
posteriores vêm delimitando a classe de eventos abrangida pelo precedente $^{140}$.

Nessa linha, Barroso e Mello observam que, para identificar a generalidade do holding, deve-se analisar alguns aspectos essenciais ${ }^{141}$, entre eles: i) os fatos relevantes; ii) a questão jurídica posta a juízo; iii) os fundamentos da decisão; e iv) a solução adotada pela Corte.

Apesar de todas as observações feitas neste capítulo, a prática demonstra que identificar a ratio decidendi pode ser uma tarefa extremamente complexa. Analisaremos, adiante, alguns dos problemas que dificultam ou até mesmo inviabilizam a identificação da norma que poderá ser aplicada a casos análogos.

${ }^{140}$ MELLO, Patrícia Perrone Campos. Op. cit., p. 135.

${ }^{141}$ BARROSO, Luís Roberto; MELLO, Patrícia Perrone Campos. Op. cit., p. 22. 


\section{Obstáculos para a identificação da ratio decidendi}

\subsection{A cultura do "ementismo"}

Quando se busca analisar o posicionamento de determinado tribunal sobre alguma questão, é comum na prática atual que se recorra à ementa dos julgados. Entretanto, essa prática pode representar um verdadeiro equívoco, pois, em diversas situações, as ementas não foram bem redigidas ou não representam a decisão do colegiado como um todo.

Primeiramente deve-se esclarecer que a ratio do precedente não se confunde com ementa e esta, por sua vez, não substitui o acórdão. Um dos primeiros obstáculos a serem superados pelo Novo Código é justamente superar a interpretação ementista do Direito brasileiro.

A esmagadora maioria das petições que assolam o judiciário estão recheadas de referências a ementas como se fossem um "atalho" fiel para a ratio decidendi do acórdão e como se representassem jurisprudência pacífica dos tribunais sobre determinada matéria, o que, muitas vezes, pode ser enganoso.

A falta de rigor na utilização do termo "jurisprudência" faz com que comumente signifique "ementas arbitrariamente selecionadas para defender determinado posicionamento, ignorando-se completamente os julgados em sentido diverso" 142 .

\footnotetext{
142 Não é difícil observar que, no Brasil, a aplicação de um precedente acontece, primeiramente, com a escolha arbitrária de uma das interpretações trazidas pelas partes e, posteriormente, a escolha se confirma com uma rápida e simples busca em algum repositório de jurisprudência por julgados (Escolhidos seletivamente pelo intérprete) que convém à tese, ignorando-se os que lhe são contrários. Nesse sentido, a ementa desempenha papel importante na seleção arbitrária do precedente, na medida em que os conceitos presentes são depurados para extrair as particularidades do caso concreto. Por essas razões, a prática e o ensino jurídicos, calcados em pressupostos ideológicos de abstrações uniformizadoras, caem como uma luva para corroborar essa interpretação da ementa.

Estas formas de interpretação/aplicação das ementas no Brasil tendem: 1) a demonstrar a confusão que fazem destas com os precedentes e 2) considerá-las com status de textos legislativos. MAGALHÃES, Breno Baía; SILVA, Sandoval Alves. "Quem vê ementa, não vê precedente: ementismo e precedentes judiciais no projeto do novo CPC". Novas tendências do processo civil:
} 
Magalhães e Silva descrevem que, com o passar dos anos, as ementas ganharam papel de destaque e, de instrumento de indexação, passaram substituir a necessidade de se recorrer às fundamentações dos julgados em busca da ratio decidendi. Alertam os autores que:

(...) uma das principais consequências da autonomização da ementa com relação ao caso julgado é que o seu texto passa a ser interpretado tal qual ao da lei e, de forma mais preocupante, tal como uma regra, que tem a pretensão de ser aplicada ao caso concreto julgado, sem qualquer responsabilidade em saber se o caso paradigma realmente tem circunstâncias generalizantes suficientes para resolver a questão futura deduzida em juízo ${ }^{143}$.

Embora em alguns casos a ementa realmente represente uma síntese do que foi decidido no acórdão, em outros não dialoga com a opinião dos demais julgadores, refletindo apenas o voto do relator. Tomemos como exemplo ${ }^{144}$ o inquérito $2.537 / \mathrm{GO}$, cuja ementa continha informação que não foi endossada pela maioria do colegiado. Segue a ementa redigida pelo Min. Marco Aurélio:

APROPRIAÇÃO INDÉBITA PREVIDENCIÁRIA - CRIME - ESPÉCIE. A apropriação indébita disciplinada no artigo 168-A do Código Penal consubstancia crime omissivo material e não simplesmente formal. INQUÉRITO SONEGAÇÃO FISCAL - PROCESSO ADMINISTRATIVO. Estando em curso processo administrativo mediante o qual questionada a exigibilidade do tributo, ficam afastadas a persecução criminal e - ante o princípio da não-contradição, o princípio da razão suficiente - a manutenção de inquérito, ainda que sobrestado.

Discordando da posição do tribunal, o ministro-relator argumentou que o delito do art. 168-A do Código Penal teria natureza omissivomaterial. Entretanto, tal consideração representava apenas sua opinião individual. O tribunal não estava revendo sua posição naquela ocasião (não houve overruling). Tanto é que, em julgamento posterior (HC 96.902/SP), no qual o impetrante sustentava alteração do entendimento da Corte com base no Inquérito 2.537/GO, a Min. Carmen Lúcia explicitou que não houve alteração do entendimento nessa ocasião, pois essa questão (mudança no entendimento sobre a natureza do crime) não fora acolhida pela maioria

estudos sobre o projeto do novo Código de Processo Civil, v. 2. Alexandre Freire et al. (coord.). Salvador: Juspodivm, 2014, p. 228.

143 Ibid. p. 213.

${ }^{144}$ MAGALLHÃES, Breno Baía. SILVA, Sandoval Alves. Op. cit., p. 213-215. 
dos ministros. A ementa ainda gerou mais problemas, pois, desconsiderando o último acórdão, o $\mathrm{TRF}-1^{\mathrm{a}}$ região sustentou, por certo período, que teria havido alteração da jurisprudência do STF acerca da natureza do referido crime.

O $\S 3^{\circ}$ do art. 489 do $\mathrm{CPC} / 2015$ dispõe que "a decisão judicial deve ser interpretada a partir da conjugação de todos os seus elementos e em conformidade com o princípio da boa-fé". Dessa forma, a ementa pura e simples não pode ser elevada a título de precedente, e, para identificar a ratio, deve-se interpretar o acórdão em sua inteireza ${ }^{145}$.

A ementa é um importante instrumento para organização, difusão e conhecimento do precedente, de forma a facilitar a localização do julgado, mas, para isso, precisa ser mais cuidadosamente redigida e não pode representar uma forma de aplicação automática de precedentes.

\subsection{Má redação das súmulas}

Observamos, no tópico anterior, que a má redação de ementas pode levar a erros sobre a posição do colegiado em determinada decisão. Mas essas não são as únicas que podem levar a esse entendimento equivocado.

De acordo com o CPC/2015, em respeito aos deveres de uniformização e publicização da jurisprudência, a súmula deve representar enunciado normativo (texto) da ratio decidendi de uma jurisprudência dominante (precedente reiterado). Assim como qualquer texto, a súmula será reinterpretada, daí a importância de ser escrita com termos precisos, que permitam a devida compreensão do precedente que foi reiterado e ensejou sua redação. Entretanto, muitas vezes não ocorre dessa forma.

Tomemos como exemplo a recentíssima Súmula $n^{\circ} 70$ do TSE, publicada em junho/2016, que dispõe que "o encerramento do prazo de

145 Veremos no tópico seguinte que, mesmo recorrendo à fundamentação dos acórdãos, pode ser difícil ou mesmo impossível identificar as razões de decidir adotadas pelo colegiado. 
inelegibilidade antes do dia da eleição constitui fato superveniente que afasta a inelegibilidade, nos termos do Art. 11, § 10, da Lei n ${ }^{\circ}$ 9.504/97”.

A partir da redação da súmula, fica claro que o candidato que tiver seu prazo de inelegibilidade terminado antes da data da eleição, poderá efetuar o registro e concorrer às eleições. Mas, pergunta-se: e se o prazo de inelegibilidade terminar depois das eleições, mas antes da diplomação? Poderíamos concluir que, contrario sensu, se o prazo não terminar antes do dia da eleição, não haveria afastamento da inelegibilidade?

Entre outras questões, esse ponto foi debatida no recurso em registro de requerimento de candidaduta $n^{\circ} 9787^{146}$ e gerou divergência entre os julgadores. Apesar da existência da súmula, foram trazidos julgados posteriores à sua publicação ${ }^{147}$ em que os mesmos ministros que participaram de sua confecção entenderam que o encerramento do prazo de inelegibilidade antes do dia da diplomação afastaria, sim, a inelegibilidade ${ }^{148} 149$.

Diversos problemas poderiam ser levantados a partir desse caso ${ }^{150}$, mas, nesse momento, o foco está em ressaltar a necessidade de maior cuidado e precisão na escolha do texto das súmulas para que, de fato, guardem fidelidade para com os julgados que ensejaram sua criação e reproduzam a ratio decidendi que estaria sendo reiteradamente aplicada.

\footnotetext{
146 Recurso Eleitoral no 9787, julgado em 10/06/2016, Rel. Des. Eleitoral André Fontes.

${ }^{147}$ Recurso Especial Eleitoral nº 2026 e ação cautelar nº 0601964-14.

148 “A Desembargadora Eleitoral Jacqueline Montenegro traz uma Súmula bastante interessante e atual. A Sumula $\mathrm{n}^{\circ} 70$ é de setembro de 2016. Mas, estranhamente, o Desembargador Eleitoral Leonardo Grandmasson traz acórdãos recentíssimos da lavra dos mesmos que participaram da confecção da referida súmula com a agora adesão do Ministro Herman Benjamin”. Recurso Eleitoral nº 9787, julgado em 10/06/2016, Rel. Des. Eleitoral André Fontes.

$149 \mathrm{O}$ caso sob análise trouxe, ainda, decisões anteriores à elaboração da súmula que parecem indicar que a interpretação prevalescente era aquela em que o fim do prazo de inelegibilidade antes da data da diplomação configuraria fato superveniente e afastaria a inelegibilidade: Embargos de Declaracao em Recurso Ordinario $n^{\circ}$ 29462, Acordao de 11/12/2014, Relator(a) Min. GILMAR FERREIRA MENDES, Publicacao: PSESS - Publicado em Sessao, Data 11/12/2014; Agravo Regimental em Recurso Ordinario no. 222398, AcOrdao de 11/12/2014, Relator(a) Min. MARIA THEREZA ROCHA DE ASS'S MOURA, Relator(a) designado(a) Min. JOSE ANTONIO DIAS TOFFOLI, Publicacao: PSESS - Publicado em Sessao, Data 11/12/2014.

150 Entre eles o problema da edição abstrata de súmulas e o fato de os próprios ministros não seguirem o enunciado da súmula e sequer mencionarem sua existência.
} 


\subsection{Falhas na deliberação interna dos tribunais}

Em tese de doutorado intitulada "As razões ocultas do Supremo Tribunal Federal: um estudo sobre agenciamento de grupo na Corte", orientada pelo Professor Noel Struchiner, Danilo dos Santos Almeida observa que, entre outras distinções, colegiados podem apresentar suas decisões como uma única voz, ou como uma multiplicidade de vozes ${ }^{151}$. As Cortes brasileiras adotam o modelo seriatim, onde cada membro do colegiado publica seu voto separadamente e o resultado do julgamento é formado pelo conjunto dessas posições individuais. Cada membro redige um documento contendo sua opinião sobre como solucionar o caso, mas a Corte como um todo não redige tal documento.

O outro modelo de decisões de grupo se chama per curiam, e, ao final do processo deliberativo, ao invés de uma soma de manifestações individuais, o grupo se manifesta como um todo. Em alguns países, as manifestações individuais são sigilosas e não se sabe como se chegou ao resultado final da corte, já outros permitem a elaboração de votos divergentes, mas, via de regra, decisões per curiam transmitem uma ideia de unicidade, coesão, de consenso da corte e as decisões seriatim, por sua vez, minimizam essa ideia, evidenciando a existência de posições dissonantes.

Quando pensamos em "acórdão" como resultado do processo deliberativo de um colegiado, é natural a associação com a ideia de entendimento comum, de acordo. Entretanto, verificamos que, em diversos casos, a decisão colegiada representa a soma de votos individuais, que concordam apenas com o resultado "procedente" ou "improcedente", mas que não dialogam quanto aos fundamentos.

\footnotetext{
151 ALMEIDA, Danilo dos Santos. As razões ocultas do Supremo Tribunal Federal: um estudo sobre agenciamento de grupo na Corte. Tese de doutorado em Direito. Pontifícia Universidade Católica do Rio de janeiro. 2016. p. 47-48.
} 
Vivenciamos o "problema da demarcação das decisões coletivas"152, uma vez que não temos um modelo interpretativo que permite de distinguir as manifestações individuais dos ministros dos posicionamentos coletivos da Corte - ao menos nos casos difíceis. A falta de uma enunciação da razão coletiva para decidir faz com que (quando e se ela de fato existe), seja potencialmente difícil de localizar.

Existe uma falta de compromisso dos ministros para formarem decisões veradadeiramente coletivas ${ }^{153}$. Ou seja, apesar de ser fruto de um colegiado, as decisões não são propriamente coletivas, representando, na verdade, um agrupamento de opiniões individuais. Algums estudiosos atribuem esse fenômeno à ocorrência de um pocesso deliberativo defeituoso.

Ressalta-se que esse defeito na deliberação pode ser tanto interno quanto externo, na medida em que os ministros não deliberam internamente durante o processo decisório e nem deliberam com as decisões anteriores da Corte. Nas palavras de Sundfeld e Pinto:

(...) o que se observa na prática institucional é que o STF, em verdade, não valoriza a jurisprudência constitucional brasileira, inclusive a que o próprio Tribunal produz. Pesquisas recentes demonstram uma série de características relacionadas ao modo de deliberar e decidir do Tribunal acabam por prejudicar a força normativa de sua jurisprudência, assim como dificultam a elaboração e comunicação das razões colegiadas para sustentar suas decisões. A própria maneira com a qual os ministros argumentam e lidam com os precedentes é representativa da pouca atenção dada à jurisprudência constitucional produzida pela Corte e pelos demais tribunais e juízes brasileiros ${ }^{154}$.

\footnotetext{
152 ALMEIDA, Danilo dos Santos. Op. cit., p. 54-60.

153 "Uma característica presente na prática do STF é a de decidir por meio de votos que se limitam a expor o resultado e os fundamentos individuais de cada julgador. Não se percebe nos acórdãos do Tribunal uma preocupação de proferir resultado acompanhado de razões colegiadas que o embasem.Antes, o que há, são peças argumentativas individuais, com frequentes variações na fundamentação, que não costumam tratar dos mesmos pontos, especialmente quando divergem. É comum que a leitura dos acórdãos revele arrazoados argumentativos construídos a partir de premissas diferentes e independentes, com trajetos apartados e baixo grau de interação entre os votos". SUNDFELD, Carlos Ari; PINTO, Henrique Motta. Três Desafios para Melhorar a Jurisdição Constitucional Brasileira. In. VOJVODIC, Adriana et al (eds.). Jurisdição Constitucional no Brasil. São Paulo: Malheiros, 2012. p. 24.

${ }^{154}$ SUNDFELD, Carlos Ari; PINTO, Henrique Motta. Op. cit., p. 23-24.
} 
Buscando entender o processo deliberativo da Corte por meio de uma análise interna, Virgílio Afonso da Silva entrevistou alguns ministros e ex ministros do STF e concluiu que eles próprios reconhecem que uma das causas da grande quantidade de votos divergentes e concorrentes - ao menos nos casos difíceis com maior repercussão social - é ausência de deliberação prévia associada à prática de levar votos prontos para a sessão de julgamento.

Nas palavras de um dos ministros:

O modo como nós trabalhamos - levar votos já preparados - não leva a um debate saudável ou produtivo [...]. A gente não sabe quais são os argumentos do outro. [...] Eu acho que há uma falha estrutural, uma falha essencial no modelo deliberativo, por isso que há votos divergentes, [...] é muito mais difícil no nosso sistema alguém voltar atrás daquilo que apresentou ${ }^{155}$.

Existe uma forte ligação entre a capacidade de consenso no colegiado e a existência de um diálogo interno. Nos tópicos seguintes explicitaremos alguns indícios de que a ausência de deliberação interna no STF pode tornar difícil a identificação de fundamentos coletivamente endossados, e, consequentemente, a extração de uma ratio decidendi do tribunal ${ }^{156}$.

\subsubsection{Divergência quanto aos pontos relevantes para a resolução das controvérsias}

A deficiência no processo deliberativo é tamanha que em alguns casos os ministros sequer chegam a uma conclusão sobre quais são os principais problemas trazidos pelo caso. Para exemplificar esse problema, Vojvodic, Machado e Cardoso ${ }^{157}$ trazem o caso Ellwanger (HC 82.424), em que o recorrente alegava que não havia cometido o crime de racismo, argumentando que judeus não representariam uma raça.

155 SILVA, Virgílio Afonso da. De Quem Divergem os Divergentes: os votos vencidos no Supremo Tribunal Federal. Direito, Estado e Sociedade, n. 47, 2015, p. 211.

156 Não consideramos que essa deficiência seja apenas do STF, mas tomaremos nos próximos tópicos esse tribunal como exemplo.

157 VOJVODIC, Adriana de Moraes; MACHADO, Ana Mara França; CARDOSO, Evorah Lusci Costa. Escrevendo um Romance, Primeiro Capítulo: Precedentes e Processo Decisório No STF. Revista Direito GV, São Paulo, n .5, vol. 1.2009. p. 31-33. 
As autoras sustentam que os ministros poderiam ser agrupados em 4 tipos de argumentos, que envolviam diferentes questões: (i) o primeiro grupo se concentrou em analisar qual seria a definição do crime de racismo; (ii) o segundo grupo se concentrou principalmente em deliberar se o crime de racismo poderia ser cometido contra judeus; (iii) o terceiro grupo concentrou-se em refletir sobre os meios pelos quais o crime de racismo poderia ser cometido; (iv) o quarto grupo focou na análise do choque "liberdade de expressão x dignidade da pessoa humana" no caso da criminalização do pensamento. Nem todos os ministros se manifestaram a respeito de todos os problemas existentes. Nas palavras das autoras:

O que se identifica no julgamento do caso Ellwanger, porém, é a escolha, por parte de cada ministro, de um problema específico que, no dizer de cada um, resume a controvérsia como um todo. No limite, ao escolherem problemas diferentes, ao invés de terem perspectivas de interpretação diferentes de um mesmo problema, cada ministro decide um caso completamente diferente ${ }^{158}$.

Apesar de todos os ministros, com exceção do relator, terem concluído que a discriminação contra judeus configura o crime de racismo e que este não estaria limitado ao fator biológico de raça, as autoras esclarecem que esse consenso quanto ao resultado do julgado não significa que todos os ministros enxergaram a mesma questão jurídica a ser decidida no caso.

A atual forma de estruturação do processo decisório permite que os ministros selecionem quais problemas querem resolver com sua argumentação, sem que necessariamente todos se pronunciem sobre eles. Diante da ausência de consenso sobre o principal problema trazido pelo caso, parece bastante difícil identificar as razões de decidir do colegiado se existirem. 


\subsubsection{A regra da maioria decisória simples}

$\mathrm{O}$ atual modelo decisório estrutural permite uma apresentação plural de soluções, propiciando a ocorrência do fenômeno da dispersão de fundamentos. Mesmo quando há uma decisão por maioria ou por unanimidade, nem sempre ela fornece elementos suficientes para que se alcancem as razões de decidir do colegiado.

A concordância entre os ministros pode se dar apenas quanto à parte dispositiva da decisão (julgo procedente ou improcedente o pedido), desconsiderando o caminho percorrido para se chegar àquele resultado. Por isso, não raras vezes, ainda que as decisões sejam unânimes ${ }^{159}$, pode não ser possível identificar a opinião da Corte, e, consequentemente, extrair a ratio da decisão.

Leite e Brando ${ }^{160}$ elencam três principais causas que contribuem para a dispersão de fundamentos no STF: (i) o princípio da causa de pedir aberta; (ii) indeterminação da linguagem; (iii) regra da maioria decisória simples.

O princípio da causa de pedir aberta preceitua que a Corte Constitucional não estaria vinculada à causa de pedir indicada pelo autor da ação, mas estaria livre para declarar a inconstitucionalidade com base em qualquer outro fundamento que entenda pertinente. Ou seja, poderiam reconhecer a inconstitucionalidade com base em qualquer norma constitucional. Entendem os autores que, se a busca por fundamentos pode ser ampla, aumentam as chances de dispersão. Entretanto, se tornássemos a causa de pedir "fechada", apesar de haver redução nas potenciais chances

\footnotetext{
159 "No Supremo Tribunal Federal, praticamente todas as decisões nos casos mais polêmicos têm votos divergentes. Mesmo naqueles casos em que a decisão final é unânime, há ao menos divergências argumentativas que podem ser relevantes. Esses são os votos que, em algumas cortes, são chamados de votos concorrentes, porque, embora não divirjam do resultado final, divergem do caminho para se chegar a ele". SILVA, Virgílio Afonso da. De Quem Divergem os Divergentes? Os votos vencidos no Supremo Tribunal Federal. Revista Direito, Estado e Sociedade, No. 47, 2016.

160 As considerações abordadas neste tópico foram retiradas de LEITE, Fábio Carvalho; BRANDO, Marcelo Santini. Dispersão de Fundamentos no STF. 2016. Manuscrito.
} 
de dispersão de fundamentos, ainda assim o fenômeno continuaria a ocorrer ${ }^{161}$. Causa de pedir "fechada" não significa que haja uma única causa de pedir, pois nada impede que a petição inicial traga mais de um fundamento.

O segundo elemento que contribui para a dispersão de fundamentos seria a indeterminação relativa do texto constitucional, que dificultaria a delimitação dos conceitos legais. Entretanto, se a linguagem do texto constitucional fosse precisa, ainda assim continuaria a ocorrer o fenômeno, uma vez que a precisão do texto não impede a ocorrência divergências quanto aos fundamentos da ação, pois a petição inicial pode apresentar mais de uma razão para a inconstitucionalidade da norma ${ }^{162}$.

O último elemento seria suficiente, por si só, para permitir a ocorrência do fenômeno da dispersão de fundamentos ${ }^{163}$. Os autores observam que, tanto o art. 97 da CRFB/88 como o art. 173 do RISTF estabelecem que a inconstitucionalidade de uma norma apenas pode ser declarada pela maioria absoluta dos membros. Entretanto, nada dispõem a respeito de como essa maioria deverá ser formada. Diante disso, a prática demonstra que a concordância da maioria não se dá quanto aos fundamentos da decisão, mas apenas quanto à conclusão (procedência ou improcedência do pedido). Os autores chamam essa prática consolidada de regra da maioria decisória simples (RMDS), e afirmam que, no julgamento das ações diretas, os fundamentos apresentados pelos ministros não têm relevância para a formação do quórum decisório ${ }^{164}$.

Questionam-se os autores se seria legítimo uma Corte invalidar uma norma aprovada pelo legislativo baseada em simples soma de votos

\footnotetext{
${ }^{161}$ LEITE, Fábio; BRANDO, Marcelo Santini. Op. cit., p. 11.

162 Ibid. p. 11.

163 Ibid. p. 11.

164 "A prática consolidada no art. 173 do Regimento Interno do STF6 é no sentido de que apenas a conclusão - e não a fundamentação - pela constitucionalidade ou inconstitucionalidade da norma seja levada em consideração. Chamaremos essa prática consolidada de regra de maioria decisória simples (RMDS). A RMDS afirma que no julgamento das ações diretas os fundamentos apresentados pelos ministros não têm relevância para a formação do quorum decisório". Ibid. p. 7 .
} 
independentemente de seus fundamentos. Estaria esse fato em consonância com a presunção de constitucionalidade das leis? Seria de se esperar que, quando não se consegue chegar a um acordo sobre o fundamento de uma inconstitucionalidade, esta não deveria ser declarada.

Parece que a RMDS operacionaliza a atividade do STF, evitando sua total paralisação decisória, mas, apesar de ser funcional, Leite e Brando sustentam que a regra possui desvantagens que podem se sobrepor às suas vantagens.

A RMDS dificulta e por vezes impossibilita a criação de precedentes, transformando o processo decisório em uma soma de decisões monocráticas. Os autores observam que resultado diferente parece que advir se a RMDS fosse transformada numa regra de maioria decisória vinculada aos fundamentos (RMDVF). Tal regra demandaria que a conclusão alcançada pelos ministros fosse amparada pela concordância em torno dos fundamentos, exigindo maior produtividade de debates, o que tornaria viável pensar na ideia de uma decisão, de fato, coletiva.

\subsubsection{O excesso de personalismo argumentativo}

Estudos empíricos indicam que o fenômeno da dispersão de fundamentos ocorre com mais frequência nos casos difíceis, de maior repercussão social. Estatisticamente, nos casos corriqueiros e repetitivos, os ministros costumam seguir o relator sem maiores problemas ${ }^{165}$, delegando a ele os fundamentos do colegiado ${ }^{166}$.

Entretanto, nos casos difíceis, de maior repercussão social, os ministros costumam levar seus votos prontos para as sessões de julgamento, sem dialogar com o voto do relator ou dos demais.

\footnotetext{
165 SILVA, Virgílio. "Um Voto Qualquer”? O papel do minis tro relator na deliberação no Supremo Tribunal Federal. Revista de Estudos Institucionais, vol. 1, n. 1, 2015, p. 187-188.

166 Essa conclusão pode ser extraída de ALMEIDA, Danilo dos Santos; BOGOSSIAN, Andre. "Nos Termos do Voto do Relator": considerações acerca da fundamentação coletiva dos acórdãos do STF. Revista de Estudos Institucionais (submetido para avaliação), 2016.
} 
Diversos são os fatores que parecem demonstrar que o STF estaria contaminado por uma extrema vaidade argumentativa, o que faz com que os ministros, ao invés de deliberarem sobre qual seria o argumento mais adequado ao caso, atuem como advogados de suas opiniões pessoais, evitando a qualquer custo reconsiderá-las. Os votos seriam, na verdade, peças argumentativas individuais repletas de razões independentes que raramente dialogam com o colegiado ${ }^{167}$.

Virgílio Afonso da Silva, em trabalho intitulado 'De quem divergem os divergentes: os votos vencidos no Supremo Tribunal Federal"168, conclui que a prática dos ministros de, nos grandes casos, levarem os votos prontos para a sessão de julgamento representaria um fator antideliberativo da Corte. A partir disso, o autor elaborou outro trabalho ${ }^{169}$ defendendo a relativização da importância do relator como condutor do debate nos casos mais relevantes. Nesses casos, cada ministro atuaria como relator do caso, elaborando seu voto individual antes da sessão.

A maior parte dos ministros parece concordar que a prática de redigir votos autônomos antecipadamente provoca um efeito antideliberativo, uma vez que dificilmente um julgador reconsidera seus argumentos ${ }^{170}$ e volta atrás em seu voto ${ }^{171}$. Paradoxalmente, todos os ministros que fazem essa crítica também levam seus votos prontos para a sessão.

\footnotetext{
167 “Mesmo quando citam juris prudência do STF, os ministros têm por hábito mencionar julgados em que eles próprios atuaram como relatores. Ao assim procederem, reforçam a tendência de que tais casos sejam lidos e compreendidos dentro da sua própria linha individual de pensamento". SUNDFELD, Carlos Ari; PINTO, Henrique Motta. Três Desafios para Melhorar a Jurisdição Constitucional Brasileira. In. VOJVODIC, Adriana et al (eds.). Jurisdição Constitucional no Brasil. São Paulo: Malheiros, 2012. p. 24-25.

168 SILVA, Virgílio Afonso da. De Quem Divergem os Divergentes: os votos vencidos no Supremo Tribunal Federal. Direito, Estado e Sociedade, n. 47, 2015, p. 205-225.

169 SILVA, Virgílio Afonso da. "Um Voto Qualquer"? O papel do ministro relator na deliberação no Supremo Tribunal Federal. Revista de Estudos Institucionais, vol. 1, n. 1, 2015, p.180-200.

170 Salvo quando deseja permanecer como relator da causa, o que parece ser mais um indício de excesso de personalismo na postura dos ministros. Nesse sentido, veja-se o depoimento do ministro R: "No caso Raposa Serra do Sol, o Britto [relator] tinha sido vencido. Quando ele percebeu que o voto do Carlos Alberto Direito era de uma densidade muito grande, ele [alterou sua posição] para ficar como relator, para assinar o acórdão.” Ibid. p. 19.

171 Virgílio traz o exemplo do do ministro T, que, "embora sustente, como visto acima, que a quantidade de votos divergentes é extremamente negativa e defenda que o 'tribunal deveria ser mais conciso e objetivo para justamente não ensejar esse tipo de personalismo', ao mesmo tempo
} 
Quando questionados a respeito da divulgação prévia do voto do relator, a maioria dos ministros parece reconhecer que contribuiria positivamente para a economia de tempo ${ }^{172}$, uma vez que, se concordasse com o relator, os demais não precisariam dispender tempo elaborando um voto escrito ${ }^{173}$. Caso o relator divulgasse seu voto antecipadamente, a prática de levar votos prontos para a sessão de julgamento possivelmente seria revista.

Entretanto, apesar de desejada por alguns ministros, a divulgação antecipada dos votos gera alguns receios, principalmente de cunho pessoal, uma vez que os ministros não desejam transformar seus votos em alvos de contra-argumentação mais robusta ${ }^{174}$. Virgílio observa que esse receio soa como vaidade e individualismo. Nas palavras de um dos ministros entrevistados pelo autor:

se eu [...] recebesse os votos dos ministros a, b e c e [...] tivesse alguma dúvida, eu telefonaria [para os autores dos votos]. Agora se se tratasse do ministro f, eu ia aproveitar para cair em cima dele, fazer uma grande discussão, transformar aquilo num debate para tentar mostrar que eu sei Direito mais do que ele ${ }^{175}$.

Os poucos ministros que são contrários à ideia de que o relator possa ou deva distribuir seu voto com antecedência entendem que levar um voto pronto significa estar bem preparado, "fazer o dever de casa". Argumentam que: i) divulgar os votos antes da sessão poderia levar muitos ministros a

afirma, da maneira mais enfática possível: 'Eu nunca, eu nunca, eu nunca retirei um voto, eu nunca retirei um voto"”. SILVA, Virgílio Afonso da. De Quem Divergem os Divergentes: os votos vencidos no Supremo Tribunal Federal. Direito, Estado e Sociedade, n. 47, 2015, p. 221.

172 Salvo o ministro N, que utilizou os argumentos "tempo" e excesso de trabalho" de forma oposta aos demais. Segundo ele, receber o voto do relator com antecedência não ajudaria muito: porque a carga de trabalho [...] é incrível, só quem está lá sabe; então, se eu tenho os meus processos e estou às voltas com os meus processos, eu não vou ter tempo de ler voto de ninguém antes da hora. Imagina se todos eles mandassem os votos, então eu ia passar a noite inteira lendo [...], não teria tempo. Então eu acho que é contraproducente [...] essa entrega do voto. SILVA, Virgílio Afonso da. "Um Voto Qualquer"? O papel do ministro relator na deliberação no Supremo Tribunal Federal. Revista de Estudos Institucionais, vol. 1, n. 1, 2015, p. 193-194.

173 Ibid. p.194.

174 Esse receio infelizmente parece ter fundamento. Veja-se trecho de uma afirmação feita pelo exministro T que me deixou bastante perplexa: "se eu [...] recebesse os votos dos ministros a, b e c e [...] tivesse alguma dúvida, eu telefonaria [para os autores dos votos]. Agora se se tratasse do ministro $\mathrm{f}$, eu ia aproveitar para cair em cima dele, fazer uma grande discussão, transformar aquilo num debate para tentar mostrar que eu sei Direito mais do que ele". SILVA, Virgílio Afonso da. "Um Voto Qualquer"? O papel do ministro relator na deliberação no Supremo Tribunal Federal. Revista de Estudos Institucionais, vol. 1, n. 1, 2015, p. 194-195.

175 Ibid. p 194-195. 
acompanharem o relator por simples inércia; ii) o grau de influência do relator poderia ser potencializado; iii) o julgamento já estaria decidido antes de iniciada a sessão de julgamento, antes de se ouvirem os advogados em suas sustentações orais, quando fosse o caso.

Esse receio, contudo, não leva em consideração a possibilidade de que primeiro sejam ouvidas as sustentações orais de advogados, procuradores e outros participantes para que, em sessão distinta, o relator apresente seu voto e haja deliberação. Esse é o modelo mais comum em tribunais constitucionais e supremas cortes ${ }^{176}$.

Virgílio observa que as entrevistas demonstram claramente que há uma diferença entre a prática atual e a dos primeiros 10 ou 15 anos de vigência da Constituição de 1988. Segundo o autor, essa mudança de comportamento parece decorrer de algumas razões, entre elas: da complexidade e do impacto moral e social dos debates propostos à Corte, bem como da transmissão das sessões de julgamento pela TV Justiça, o que poderia exigir uma preparação mais intensa dos ministros através da elaboração de um voto escrito ${ }^{177}$.

Apesar de a maioria das decisões do STF serem monocráticas ou sem votos divergentes, uma vez que nos casos repetitivos os ministros costumam seguir o relator sem maiores considerações, devemos ressaltar que, nos casos mais relevantes, o fenômeno da dispersão de fundamentos se faz presente, impedindo que o leitor dos acórdãos identifique os fundamentos do colegiado e extraia a ratio decidendi do julgado.

Conrado Hübner Mendes propõe que uma corte verdadeiramente deliberativa deveria manifestar-se nesse sentido em três etapas: (i) prédecisional; (ii) decisional e (iii) pós decisional ${ }^{178}$.

\footnotetext{
176 Ibid. p 194-195.

177 Ibid. p. 191.

178 MENDES, Conrado Hübner. O projeto de uma corte deliberativa. In. VOJVODIC, Adriana et al (eds.). Juris dição Constitucional no Brasil. São Paulo: Malheiros, 2012. p. 59.
} 
Apesar de não ocorrerem necessariamente em uma ordem linear e nem sempre haver limites bem definidos entre as três fases, de uma maneira geral, a fase pré-decisional começaria com a existência concreta do litígio e contemplaria todos os atos de interação entre as partes e a corte. Após essa primeira etapa, inicia-se a fase decisional, onde os julgadores interagem entre si na busca da melhor solução. E, por fim, viria a fase pós-decisional, abarcando a elaboração do texto da decisão, bem como uma análise das consequências e reações que esta poderá gerar na esfera pública informal. Essa última fase pode, ainda, representar uma fase pré-decisional para um caso posterior ${ }^{179}$.

O autor ressalta a importância do cuidado na escolha do texto do acórdão, uma vez que este assume o compromisso de refletir o resultado final do processo deliberativo da corte. "O estilo redacional de uma decisão cumpre uma função quase tão fundamental quanto seu próprio conteúdo"180. Além disso, é essencial que a corte analise profundamente as consequências de expor eventuais desacordos internos. Uma corte deliberativa não deve publicizar a existência de qualquer tipo de desacordo, mas apenas aqueles que representem considerações sérias, que resistiram a uma profunda deliberação e que não sejam decorrentes de meros caprichos $\operatorname{argumentativos}^{181}$.

Parece que, em diversas situações, ministros não compreendem que deliberação não é uma competição onde ganha quem tem o melhor argumento, e sim um compromisso de diálogo que resulta na melhor decisão com um mínimo de dissenso ${ }^{182}$.

\footnotetext{
179 Ibid. p. 59-60.

180 Ibid. p. 65.

181 "Uma corte deliberativa não exibe publicamente um tipo qualquer de desacordo, mas somente aqueles que resistiram à interação colegiada. As divisões, quando persistem, são sérias e respeitáveis, não frívolas e caprichosas" Ibid. p.65.

182 "Deliberação não é um duelo verbal. Não é conduzida, por isso, no mesmo espírito de uma competição. O parâmetro da interação colegada requer que juízes escutem e incorporem as razões dos seus pares, seja para aderir ou para dissentir. Não são obrigados a esconder ou suprimir desacordos, mas comprometidos com uma argumentação franca em busca da melhor resposta. (...) Quando o acordo substantivo se mostra impossível, os predicados formais do Estado de Direito -
} 
Decisões seriatim não deliberativas ${ }^{183}$, comuns em nossa prática decisória atual, são o tipo mais problemático de acórdão ${ }^{184}$, pois representam um descaso com qualquer promessa de deliberação, mesmo que cada opinião individual tente argumentar da melhor maneira possível. Uma maior deliberação não significa necessariamente que não existirão discordâncias, ou que seja necessário deixar de publicar razões individuais, mas é essencial que membros de um colegiado se empenhem ao máximo para chegar à melhor decisão verdadeiramente coletiva para que possamos, de fato, falar na formação de precedentes.

tais como a certeza, previsibilidade e a segurança jurídicas - podem ser razões de segunda ordem a estimular concessões mútuas. A deliberação, de qualquer modo, não é apenas um instrumento para a produção de consenso, mas também para a produção de uma boa decisão, independentemente da unanimidade". Ibid. 62-63.

183 "Uma setiatim não deliberativa, nessa perspectiva, assemelha-se a uma colcha de retalhos decisões individuais coladas lado a lado, que não convers am entre si. A falta de comunicação entre as opiniões dificulta, ademais, a realização de promessas formais do Estado de Direito, pois sequer consegue fornecer uma ratio decidendi compartilhada, um precedente que de fato oriente casos futuros". Ibid. p. 66.

184 ALMEIDA, Danilo dos Santos. Op. cit., p. 66. 


\section{CONCLUSÃO}

Vivemos um momento de profundo descrédito no sistema judiciário, que não age como se fosse um sistema único, assemelhando-se mais a um amontoado de micropoderes, onde cada magistrado decide de acordo com o que lhe parece mais adequado, sem se ver persuadido a considerar as decisões dos tribunais superiores ou mesmo as suas próprias decisões pretéritas.

Diante disso, torna-se extremamente necessário a concretização de um sistema de valorização de precedentes que atue como uma forma de controle do poder judiciário e que permita aos jurisdicionados identificar o direito que emana dos tribunais.

São muitos os obstáculos a serem superados pelo Novo Código de Processo Civil para efetivar o respeito aos precedentes, mas de nada adianta falar em um sistema de valorização de precedentes se sequer for possível identificar dentro do julgado a fundamentação endossada pelo colegiado e que poderá originar a norma que vinculará casos futuros.

Nesses poucos meses de vigência da nova lei, são muitas as divergências. Diverge-se quanto ao conceito de precedente, diverge-se se Novo Código estabeleceria um rol de precedentes vinculantes ou não, diverge-se sobre como identificar a ratio decidendi. Entretanto, parece que a maioria consigue perceber que os tribunais encontram-se assoberbados, que é essencial um empenho em uniformizar a jusprudência e que para isso precisamos superar diversos problemas, entre eles uma reformulação das práticas processuais e dos processos deliberativos dos tribunais.

Sabe-se que qualquer mudança que possa vir a ocorrer no sistema judiciário será lenta e que por ora teremos que lidar com diversas deficiências do sistema, mas espera-se que o Novo Código de Processo 
Civil represente ao menos um primeiro passo no caminho para implementação de um sistema de valorização aos precedentes. 


\section{REFERÊNCIAS BIBLIOGRÁFICAS}

ALMEIDA, Danilo dos Santos. As razões ocultas do Supremo Tribunal Federal: um estudo sobre agenciamento de grupo na Corte. Tese de doutorado em Direito. Pontifícia Universidade Católica do Rio de janeiro. 2016.

ALMEIDA, Danilo dos Santos; BOGOSSIAN, Andre. "Nos Termos do Voto do Relator": considerações acerca da fundamentação coletiva dos acórdãos do STF. Revista de Estudos Institucionais (submetido para avaliação), 2016.

ÁVILA, Humberto. Teoria dos princípios: da definição à aplicação dos princípios jurídicos. $4^{\mathrm{a}}$ ed., $3^{\mathrm{a}}$ tir. São Paulo: Malheiros, 2005.

BARROSO, Luís Roberto; MELlO, Patrícia Perrone Campos. Trabalhando com uma nova lógica: a ascensão dos precedentes no direito brasileiro. Disponível em: http://s.conjur.com.br/dl/artigo-trabalhandologica-ascensao.pdf. Acessado em 10/11/2016.

CÂMARA, Alexandre Freitas. O novo processo civil brasileiro. São Paulo: Atlas, 2015.

CRAMER, Ronaldo. Precedentes Judiciais: teoria e dinâmica. Rio de Janeiro: Forense, 2016.

DIDIER JR., Fredie; BRAGA, Paula Sarno; OLIVEIRA, Rafael Alexandria de. Curso de direito processual civil, v. 2. 10 ed. Salvador: Juspodivm, 2015.

LEITE, Fábio Carvalho; BRANDO, Marcelo Santini. Dispersão de Fundamentos no STF. 2016. Manuscrito. 
MAGALHÃES, Breno Baía; SILVA, Sandoval Alves. "Quem vê ementa, não vê precedente: ementismo e precedentes judiciais no projeto do novo CPC". Novas tendências do processo civil: estudos sobre o projeto do novo Código de Processo Civil, v. 2. Alexandre Freire et al. (coord.). Salvador: Juspodivm, 2014.

MARINONI, Luiz Guilherme. Precedentes Obrigatórios. 4a ed. rev. atual. e amp. São Paulo: Editora Revista dos Tribunais, 2016.

MELLO, Patrícia Perrone Campos. Precedentes. Rio de Janeiro: Renovar. 2008.

MENDES, Conrado Hübner. O Projeto de uma Corte Deliberativa. In. VOJVODIC, Adriana et al (eds.) Jurisdição Constitucional no Brasil. São Paulo: Malheiros, 2012.

REDONDO, Bruno Garcia. Precedente Judicial no Direito Processual Civil Brasileiro. In: MENDES, Aluísio Golçaves de Castro; MARINONI, Luiz Guilherme; WAMBIER, Teresa Arruda Alvim (coord.). Direito jurisprudencial: volume 2. São Paulo: RT, 2014.

SCHAUER, Frederick. Precedent. Stanford Law Review, Palo Alto, v. 39, Feb. 1987.

SILVA, Virgílio Afonso da. De Quem Divergem os Divergentes: os votos vencidos no Supremo Tribunal Federal. Direito, Estado e Sociedade, n. 47, 2015.

SILVA, Virgílio Afonso da. 'Um Voto Qualquer”? O papel do ministro relator na deliberação no Supremo Tribunal Federal. Revista de Estudos Institucionais, vol. 1, n. 1, 2015. 
STRECK, Lênio Luiz; ABBOUD, Georges. O solilóquio epistêmico do ministro Roberto Barroso sobre precedentes. Disponível em: http://www.conjur.com.br/2016-nov-03/senso-incomum-soliloquioepistemico-ministro-barroso-precedentes. Acessado em: 09/11/2016.

STRECK, Lênio. Precedentes? Decisão de 4 linhas do STF contém três violações ao CPC. Disponível em: http://www.conjur.com.br/2016-nov10/senso-incomum-precedentes-decisao-linhas-stf-contem-tres-violacoescpc. Acesso em 24/11/2016.

STRUCHINER, Noel. "O direito como um campo de escolhas: Por uma leitura das regras prescritivas como relações". In: José Rodrigo Rodriguez; Carlos Eduardo Batalha da Silva e Costa; Samuel Rodrigues Barbosa. (Org.). Nas Fronteiras do Formalismo. 1ed.São Paulo: Saraiva, 2010.

STRUCHINER, Noel; SHECAIRA, Fábio Perin. Teoria da argumentação jurídica. Rio de Janeiro: Contraponto. 2016.

SUNDFELD, Carlos Ari; PINTO, Henrique Motta. Três Desafios para Melhorar a Jurisdição Constitucional Brasileira. In. VOJVODIC, Adriana et al (eds.) Jurisdição Constitucional no Brasil. São Paulo: Malheiros, 2012.

VOJVODIC, Adriana de Moraes; MACHADO, Ana Mara França; CARDOSO, Evorah Lusci Costa. Escrevendo um Romance, Primeiro Capítulo: Precedentes e Processo Decisório No STF. Revista Direito GV, São Paulo, n .5, vol. 1.2009 . 